\title{
The 'New Firm Paradigm' and the Provision of Training: The Impact of ICT, Workplace Organization and Human Capital ${ }^{a}$
}

\author{
Heinz Hollenstein ${ }^{\mathrm{b}}$ and Tobias Stucki ${ }^{\mathrm{b}}$
}

JEL-Classification: J2, L2, O3, M5

Key words: Firm-based training; Apprenticeship; ICT; Workplace organization; Human capital formation

\section{Introduction}

Over the last twenty years a significant shift in the employment structure from low to high skills has taken place in advanced economies. Several factors are hypothesized to have driven this development. To mention are, on the demand side, a skill-bias of technical change (in particular the diffusion of ICT) and a similar skill-bias of the redesign of workplace organization. Moreover, increasing specialization onto the production of knowledge intensive goods in the process of globalization also shifted labor demand towards higher skills. On the supply side, the long term trend towards higher education as well as increasing preferences of employees for workplaces involving more autonomy contributed to the observed increase in the employment of highly qualified personnel.

According to the literature, the demand side elements, in particular the diffusion of ICT and adaptations of workplace organization are the key factors driving the observed increase of the share of high skilled workers in total employment. Moreover, the interplay of these forces seems to accentuate the shift towards higher skills, although only a few studies find clear evidence for such

a This study was funded by the Swiss Federal Office for Professional Education and Technology (OPET) through its Leading House on the Economics of Education, Firm Behaviour and Training Policies. The views expressed herein are those of the authors and do not necessarily reflect the views of the OPET or the Leading House. Any remaining errors are the responsibility of the authors. The authors gratefully acknowledge the useful comments and suggestions of Uschi Backes-Gellner, Stefan Wolter and the members of the Advisory Board. Moreover, we thank Spyros Arvanitis, Peter Egger and Ulrich Kaiser for helpful comments and suggestions.

b ETH Zurich, KOF Swiss Economic Institute, CH-8092 Zurich. 
complementarities (e.g., Arvanitis, 2005; BertscheK and Kaiser, 2004; Bresnahan et al., 2002; Piva et al., 2005). According to Caroli (2001), who discusses in detail the role of the variables involved, ICT may be considered as the enabling factor triggering off a redesign of workplace organization.

Many authors conceptualized these interrelated changes as a shift towards a 'new firm paradigm', which they characterized using different labels: from a 'mechanistic' to an 'organic' firm structure (Burns and Stalker, 1994), from the 'mass production model' to the 'flexible multiproduct firm' (Milgrom and Roberts, 1990), or from a 'tailoristic' to a 'holistic' organization of work (LindBECK and SNOwER, 2000).

Since ICT is likely to provoke new challenges of adapting a firm's organization and human resource practices, there might be a sustained need to increase the stock of human capital of firms and the economy as a whole. Obviously, there are many different ways of achieving this objective. In this paper we concentrate on apprenticeship training, which in Switzerland, similar to the other German-speaking countries, is a widespread practice of skill formation at the upper-secondary level.

In Switzerland, about $70 \%$ of a cohort strives for a vocational qualification. $75 \%$ of them pass through the apprenticeship system, $25 \%$ attend full-time vocational schools. The so-called 'dual system' of apprenticeship-based vocational training combines education at a vocational school of one or two days a week, where general and occupation-specific skills are acquired, with work of three to four days a week in the training company, where learning is concentrated on occupation-specific and firm-specific skills.

Since the 1990s, a certain shift in the content of apprenticeship training towards a higher proportion of general skill provision has taken place, in an attempt to better meet the demand of companies in a knowledge-based economy. To this end, the institutional arrangement of apprenticeship was adapted, with the introduction of a second, more demanding stream of training as the change with the most far-reaching consequences. It is based on an extension of the offthe-job apprenticeship training component and leads to a degree ('Berufsmatura') that guarantees free access to non-academic, vocational-oriented, tertiary-level education ('Fachhochschule', i.e. 'university of applied sciences'). The creation of a 'Berufsmatura' degree, which has been attained by one out of six apprentices in

1 For an international comparison of several systems of vocational skill formation in European countries, see e.g. STEEDMAN $(2001,2005)$, or RyAN (2001) who emphasizes the labor market experience of graduates from different types of vocational training. 
2005, makes this type of secondary education more attractive for school leavers as well as for companies (for similar developments in Germany, see FINEGOLD and WAGNeR, 2002).

The present paper aims at identifying econometrically the determinants of apprenticeship training based on firm-level data. In doing so, we focus on the three constituent elements of the new firm paradigm, i.e. intensive use of ICT, redesign of workplace organization and augmenting the input of human capital. We try to explain why a firm does or does not provide apprenticeship training ('training propensity'), and, if doing so, to what extent a firm is engaged in this type of training ('training intensity'). The investigation is expected to give some indication of the appropriateness of the apprenticeship system as a way of skill formation in a highly advanced knowledge-based economy where the new firm paradigm plays a significant role.

The data used in this study stem from two surveys conducted in 2000 and 2005, respectively, and cover the whole business sector of the Swiss economy. By merging the two cross-sectional data sets we got an unbalanced panel with about 3500 firms, of which about 3000 could be used in model estimation. The data set is rich in terms of variables that potentially explain the firms' provision of apprenticeship training. Furthermore, the data set allows us to deal with potential econometrical problems such as endogeneity and firm heterogeneity.

The empirical literature dealing, by use of econometric methods, with a firm's demand for apprentices did not pay much attention to the influence of ICT and workplace organization. To our knowledge, only Arvanitis (2010), Arvanitis and StUCKi (2011) and Beckman $(2002,2008)$ included ICT as an explanatory variable and, so far, the impact of workplace organization has not been econometrically investigated at all. In contrast, human capital is a standard variable used in such studies (see, among many others, Beckmann, 2008; Franz et al., 2000; NiederALT, 2004). Moreover, we are not aware of any study dealing with apprenticeship training which takes account of complementarities among the three core variables.

Against this background, the paper provides new insights into the determinants of the firms' provision of apprenticeship training by focusing on the relevance of the three constituent elements of the new firm paradigm and their interaction. Given the rich database, we are able to analyze the topic in a more differentiated way than it has been done in previous studies.

The remainder of the paper is organized as follows: In Section 2, we present the conceptual background of the study as well as the hypotheses to be tested and the specification of the variables we used in model estimation. In the next two sections, we shortly describe the database and expose the econometric procedure we applied in explaining a firm's training propensity and training intensity. The 
findings from model estimation are presented in Section 5. Finally, we discuss the main results and draw some conclusions.

\section{Conceptual Background and Model Specification}

\section{Basic Approach}

The seminal paper of BECKER (1964) serves as starting point of our investigation. In his model, firms as well as apprentices conceive firm-based training as an investment in human capital enabling both parties to profit from higher productivity in the future. The firm, however, provides training only if the expected productivity gains are higher than the costs it has to bear. Whether this is the case depends on the type of skills generated by training (general vs. firm-specific knowledge), the costs of training (net of the trainees' productive contribution and subsidies) and the functioning of the market for skilled labor. If labor markets work perfectly well (what is assumed in Becker's model), a firm provides general (transferable) skill training only at zero net costs. It is not prepared to bear higher costs, since the trainees can leave the firm at the end of the apprenticeship at any time in search of higher wage offers.

In older empirical work the authors were puzzled by the finding that net costs of apprenticeship training were positive in many occupations. Therefore the investment theory of training has been further developed, with ACEMOGLu and Pischke $(1998,1999)$ probably the most influential contributions (see also Dustman and Schönberg, 2009; Elbaum and Sing, 1995; Finegold and Wagner, 2002; Franz and Soskice, 1995; Harhoff and Kane, 1997; KesSLER and LÜLfESMANN, 2006; RYAN and Wolter, 2011). This literature explains the empirical finding of widespread net costs of firm-based training mostly with labor market imperfections: asymmetric information between the training firm and other companies about the trainees' productivity; unions and work councils enforcing firms to accept net training costs during apprenticeship; mobility costs (job search, costs of introduction at a new job etc.; the fact that general and firmspecific skills often are complements provided as a package.

In accordance with these studies, the "classical" line of empirical research dealing with this topic is characterized by (direct) accounting of the firms' costs and benefits of apprenticeship training, hence net training costs. ${ }^{2}$ We choose a

2 See, among others, for Switzerland: Wolter and Schweri (2002), Schweri et al. (2003); for Germany Beicht et al. (2004), and for a comparison of the two countries Muenlemann et al. (2010). 
different approach. Our main focus is not on the cost of apprenticeship training but on the impact of the core elements of the new firm paradigm on apprenticeship training. Nevertheless, we include several variables to account at least partly for training costs. In this perspective we use as explanatory variables - in addition to the variables we are specifically interested in (human capital, ICT, workplace organization) - a detailed set of dummy variables controlling for firm size, industry affiliation and regional location (in total 39 dummies) and take account of a firm's average labor costs. In this way the different environment and characteristics of firms with respect to wage setting for apprentices and other labor categories (e.g. differences between regional labor markets and education systems; industries of different technology intensity, etc.) is accounted for.

As mentioned in Section 1, there is not much literature dealing with the impact of the variables representing the new firm paradigm on apprenticeship training (see the references in the introductory section). To our knowledge, the effect of workplace organization on the provision of apprenticeship training so far has not been analyzed. There are a few studies investigating the impact of ICT on offering apprenticeships. In contrast, human capital is widely used as variable explaining training provision. In these circumstances, it is difficult to formulate well founded hypotheses on the effect of the new firm paradigm on the provision of apprenticeship training.

In absence of clear hypotheses with respect to the influence of ICT and workplace organization, our approach makes use of the fact that apprenticeship training is a special form of human capital formation. Therefore, we use as theoretical background of the paper the literature analyzing theoretically and empirically the influence exerted by a change of ICT intensity and workplace organization on human capital, or more precisely, on the relative demand for skilled labor. In this view, the willingness of a firm to invest in apprenticeship training, in the first place, depends on all factors that determine its future demand for skilled labor. Despite the fact that firms have the possibility to hire trained apprentices from other firms, this implies that firms confronted by a large future demand for skilled employees will not only hire this category of workers on the market but, on average, are also willing to train apprentices themselves.

To sum up, we use the following categories of variables that may influence future demand for labor skills and therefore the likelihood a firm offers apprenticeship places: a) human capital intensity; b) intensity of ICT use; c) (new) workplace organization; d) control variables such as average wages and some general firm characteristics (size, foreign/domestic ownership); e) dummy variables capturing effects not explicitly specified in the model (region, industry affiliation, time). In the following we discuss the impact of the explanatory variables and 
show how they are specified in the empirical model (see Table 1 for the exact definition of the variables).

\section{Human Capital}

One of the constituent elements of the new firm paradigm is a shift from lower to higher skills. Since the share of employees holding high-level and medium-level degrees is correlated, a firm's human capital endowment should reflect the future demand for skilled labor in general. We thus posit the following hypothesis:

H1: A firm's human capital endowment is positively correlated with the provision of apprenticeship training.

We use the share of employees holding a degree from tertiary education as proxy for a firm's human capital input (variable 'tertiary_share'). ${ }^{3}$ In some instances, this share is transformed to five dummy variables 'tertiary_ $d$ ' representing different value ranges of 'tertiary_share'. Qualifications at the tertiary level are based, on the one hand, on academic education (primarily implying the production of general knowledge on top of general upper-secondary education), on the other hand, on more vocational-oriented education provided by universities of applied sciences and higher professional schools (to a large part as a follow-up to apprenticeship training). This second component, measured by its share in total tertiary education, weighs much more in Switzerland than in most other advanced economies. To capture potential differences between the two groups of tertiary level employees, their impact is also tested separately.

3 In the literature dealing with the effect of ICT on labor demand very different indicators are used to capture a firm's human capital input (see the overview of ARVANitis and Loukis, 2009). In this study we focus on the share of employees holding a degree from tertiary education, as this is the most common and empirically well-supported measure of human capital intensity. 
Table 1: Variable Definition and Measurement

\begin{tabular}{|c|c|}
\hline Variable & Definition / measurement \\
\hline \multicolumn{2}{|l|}{ Dependent Variables } \\
\hline training_propensity & Having at least one apprentice yes/no (training propensity) \\
\hline training_intensity & $\begin{array}{l}\text { Total number of apprentices (training intensity) (only firms having } \\
\text { apprentices) }\end{array}$ \\
\hline \multicolumn{2}{|l|}{ Independent Variables } \\
\hline \multicolumn{2}{|l|}{ Human capital } \\
\hline tertiary_share & Share of employees with a tertiary-level degree; logarithm \\
\hline tertiary_d & $\begin{array}{l}\text { Dummy variables for different shares of employees with a tertiary- } \\
\text { level degree (reference group: 'less than 3\%' (10th percentile)) } \\
\text { tertiary_d1: 3-6\% (25th percentile); tertiary_d2: 6-13\%(50th } \\
\text { percentile); tertiary_d3: } 13-23.6 \% \text { (75th percentile); tertiary_- } \\
\text { d4: } 23.6-43 \% \text { (90th percentile); tertiary_d5: } 43-100 \%(100 \text { th } \\
\text { percentile) }\end{array}$ \\
\hline university_tertiary & Share of employees with a university degree; logarithm \\
\hline non-university_tertiary & $\begin{array}{l}\text { Share of employees with a non-university tertiary degree (degree } \\
\text { from university of applied science or higher vocational education } \\
\text { and training); logarithm }\end{array}$ \\
\hline \multicolumn{2}{|c|}{ Information and Communication Technology (ICT) } \\
\hline ICT_infrastructure & $\begin{array}{l}\text { ICT infrastructure } \\
\text { (four-level ordinal variable constructed as the sum of four } \\
\text { dummies measuring the availability of different elements of ICT } \\
\text { infrastructure: 1) personal computer; 2) Internet; } 3 \text { ) intranet; 4) } \\
\text { extranet) }\end{array}$ \\
\hline intranet_use_d & $\begin{array}{l}\text { Share of employees regularly using the intranet } \\
\text { (dummy variables with } 0-20 \% \text { as reference group: } 21-60 \% \\
\text { (intranet_use_d1); } 61-100 \% \text { (intranet_use_d2)) }\end{array}$ \\
\hline Internet_variety & $\begin{array}{l}\text { Variety and complexity of Internet applications } \\
\text { (eight-level ordinal variable constructed as the sum of eight } \\
\text { dummies measuring different types of Internet usage: 1) general } \\
\text { search for information; 2) detailed search for market/price } \\
\text { information; 3) presentation of the firm; 4) supply of product } \\
\text { information; 5) internal communication; 6) further training; 7) } \\
\text { E-purchasing; 8) E-selling) }\end{array}$ \\
\hline ICT_total & $\begin{array}{l}\text { Overall measure for ICT usage } \\
\text { (sum of the standardized values (average } 0 \text {; standard deviation } 1 \text { ) of } \\
\text { the three ICT variables) }\end{array}$ \\
\hline
\end{tabular}




\section{Table 1 continued}

\begin{tabular}{|c|c|}
\hline Variable & Definition / measurement \\
\hline \multicolumn{2}{|l|}{ Workplace Organization } \\
\hline$\Delta \_$hierarchical_levels & $\begin{array}{l}\text { Change of the number of hierarchical levels in the preceding five } \\
\text { years (decrease (value 1); otherwise (value } 0) \text { ) }\end{array}$ \\
\hline$\Delta \_$delegation & $\begin{array}{l}\text { Change of the degree of delegation of competencies in the } \\
\text { preceding five years (increase (value 1); otherwise (value } 0) \text { ) }\end{array}$ \\
\hline team_work & $\begin{array}{l}\text { Incidence of team work } \\
\text { (six-level ordinal variable, ranging from 'very high' (value 5) to } \\
\text { 'does not exist' (value 0)) }\end{array}$ \\
\hline job_rotation & $\begin{array}{l}\text { Incidence of job rotation } \\
\text { (six-level ordinal variable, ranging from 'very high' (value 5) to } \\
\text { 'does not exist' (value 0)) }\end{array}$ \\
\hline decentralization & $\begin{array}{l}\text { Degree of decentralization of competencies: } \\
\text { (mean of seven ordinal variables ranging from 'line manager decides } \\
\text { alone' up to 'employee decides alone'; 5-point scale: 1) speed of } \\
\text { work, 2) procedures of work, 3) distribution of tasks, 4) modality } \\
\text { of the execution of tasks, 5) problems in production, 6) regular } \\
\text { contact with clients, 7) complaints of clients) }\end{array}$ \\
\hline WO_total & $\begin{array}{l}\text { Overall measure for workplace organization } \\
\text { (sum of the standardized values (average } 0 \text {; standard deviation } 1 \text { ) of } \\
\text { all five organization variables) }\end{array}$ \\
\hline \multicolumn{2}{|l|}{ Control variables } \\
\hline labor_costs & Labor costs per employee; logarithm \\
\hline size_d & $\begin{array}{l}\text { Dummy variables for six firm size classes based on the number of } \\
\text { employees (reference group: 'less than 20') } \\
\text { 20-49 (size_d1); 50-99 (size_d2); 100-249 (size_d3); 250-499 } \\
\text { (size_d4); 500-999 (size_d5); } 1000 \text { and more (size_d6) }\end{array}$ \\
\hline foreign_owned & $\begin{array}{l}\text { Foreign-owned firm } \\
\text { yes (value } 1 \text { ), no (value } 0 \text { ) }\end{array}$ \\
\hline region_d & $\begin{array}{l}\text { Dummies for six regions } \\
\text { (reference region: Ticino) } \\
\text { Lac Léman (region_d1); Espace Midland (region_d2); North- } \\
\text { western Switzerland (region_d3); Zurich (region_d4); Eastern } \\
\text { Switzerland (region_d5); Central Switzerland (region_d6) }\end{array}$ \\
\hline industry_d & $\begin{array}{l}\text { Dummies for } 27 \text { industries } \\
\text { (reference industry: 'personal services') }\end{array}$ \\
\hline year_2005 & $\begin{array}{l}\text { Time dummy for the year } 2005 \\
\text { (reference: year 2000) }\end{array}$ \\
\hline
\end{tabular}


Table 1 continued

\begin{tabular}{ll}
\hline Variable & Definition / measurement \\
\hline $\begin{array}{l}\text { Instruments } \\
\text { industry_wage_individual_ } \\
\text { performance }\end{array}$ & $\begin{array}{l}\text { Average industry (3-digit-level) score of the impact of individual } \\
\text { performance on wage level (original variable is defined as a five- } \\
\text { level ordinal variable; level 1: 'very weak'; level 5: 'very strong') }\end{array}$ \\
$\begin{array}{l}\text { industry level of intranet } \\
\text { use }\end{array}$ & $\begin{array}{l}\text { Average industry (3-digit-level) score of the share of employees } \\
\text { regularly using the intranet (original variable is defined as } \\
\text { 'intranet_use') }\end{array}$ \\
$\begin{array}{l}\text { industry level of } \\
\text { decentralization }\end{array}$ & $\begin{array}{l}\text { Average industry (3-digit-level) score of the degree of } \\
\text { decentralization of competencies (original variable is defined as } \\
\text { 'decentralization') }\end{array}$ \\
$\begin{array}{l}\text { industry level of tertiary } \\
\text { share }\end{array}$ & $\begin{array}{l}\text { Average industry (3-digit-level) score of the share of employees } \\
\text { with a tertiary-level degree; logarithm (original variable is defined } \\
\text { as 'tertiary_share') }\end{array}$ \\
\hline
\end{tabular}

\section{ICT Usage}

A more intensive use of ICT shifts the relative demand for qualified labor upwards. The literature mentions several properties of ICT driving the substitution of lower skills: a) ICT allows automating routine and well-defined tasks; it is much more difficult to do the same in case of complex tasks involving judgment and creativity (Autor et al., 2003; Bresnahan, 1999; Bresnahan et al., 2002); b) highly computerized systems produce large quantities of data that need high-skilled workers to get adequately utilized (ARVANiTIs, 2005); c) the adoption of ICT itself and its integration in the firm's productive system requires skilled workers, the more so as the use of ICT involves many uncertainties (CAROLI, 2001).

Whereas the positive effect of ICT on the demand for skilled labor as a whole is quite clear, it is less obvious which category of higher skills will 'profit' from this technical change. According to the results of the related empirical work published in the last fifteen years (see the synoptical review of ArVanitis, 2005, which was updated by Arvanitis and Loukis, 2009) the demand for graduates from universities increases in parallel with a more intensive use of ICT, whereas the evidence with respect to medium skills is mixed (positive or neutral effect). Moreover, the majority of empirical studies finds that the demand for skills at the higher intermediate level (vocational-oriented qualifications below a 
university degree but higher than medium skills) is positively affected. In view of these results we expect that the intensity of ICT usage is positively related to the demand for apprentices.

$\mathrm{H} 2$ : Intensive use of ICT, in total as well as differentiated by specific dimensions of ICT use, positively affects a firm's demand for apprentices.

There are many possible indicators to capture the intensity of ICT use (see, e.g., Bocquet and Brossard, 2007; European Commission, 2007b; Hollenstein et al., 2003). In the present study we rely on three variables that are expected to positively affect the provision of apprenticeships (for details of measurement see Table 1): a) 'ICT_infrastructure' captures a firm's endowment with technical ICT infrastructure (ordinal variable representing the number of up to four ICT elements: PC, Internet, intranet, extranet); b) 'intranet_use_d'stands for the broadness of use of ICT measured by two dummy variables reflecting, respectively, 'medium' and 'high intensity' of use of the intranet; the latter dummy should exert a stronger (positive) influence on the provision of apprenticeships than the former. The two dummies are based on originally quantitative data of the share of employees regularly working with the intranet; c) 'Internet_variety' indicates the variety and complexity of Internet applications. The measurement of this variable is based on detailed information about the purposes for which a firm employs the Internet, ranging from simple 'search for information' up to more demanding functions like 'E-selling'; the value of this ordinal variable simply represents the number of (up to eight) applications as shown in Table 1. Finally, to account for all three aspects of ICT at once, we also consider an overall measure of ICT use ('ICT_total') calculated as the sum of the standardized values of the three individual ICT variables.

\section{Workplace Organization}

According to CAROLI (2001) flattening hierarchies, decentralization of decision making, greater involvement at the shop floor, collective work practices (teamwork, quality circles, etc.), multi-tasking and job rotation are the core elements of a workplace organization that fits into a production system characterized by an intensive use of ICT. A redesign of workplace organization along these lines reflecting the new firm model is expected to increase, similar to a more intensive use of ICT, the demand for high skills at the expense of unskilled workers (skillbiased organizational change; see Piva et al. (2005) and the literature reviewed by these authors). 
However, empirical studies show that the different aspects of workplace organization are not correlated to the same extent with the demand for higher skills. In the Swiss case, for example, teamwork and some aspects of delegation of competencies are positively related to the demand for high skills, whereas flattening of hierarchies or job rotation are not (ARVANitis, 2005).

Against this background, we formulate two hypotheses with respect to the impact of new workplace organization on a firm's provision of apprenticeship training.

H3a:The redesign of workplace organization as a whole is positively related to apprenticeship training (reflecting the overall shift to higher skills induced by new workplace organization).

H3b:This holds true only for some of the five dimensions of workplace organization distinguished below. As a consequence, the overall effect, mentioned in H3a may not be very strong.

Our empirical model contains most of the above-mentioned organizational dimensions. At the level of the firm as a whole, we consider the 'change of the number of hierarchical layers' having occurred during the five year period preceding the survey of 2000 and 2005, respectively (' $\Delta_{-}$hierarchical_levels'). The variable ' $\Delta$ _delegation' captures the 'change of the degree of delegation of competencies at the workplace' that happened in the course of the preceding five years. The two variables 'team_work' and 'job_rotation' stand for the current level of diffusion of teamwork (quality circles, semi-autonomous production teams, etc.) and job rotation, respectively. Moreover, we rely on a composite measure of the 'distribution of competencies at the work place among managers and workers' ('decentralization'). This variable reflects a firm's assessment of the degree of decentralization of decision-making at the workplace in seven specific matters ('who decides on the work pace?', 'who is responsible for handling the complaints of clients? etc.; for details see Table 1). In addition to these variables that capture five specific aspects of new workplace organization, we also use an overall measure ('WO_total') which is calculated as the sum of the standardized values of the variables representing the individual elements of workplace organization.

According to hypothesis H3b, we do not expect that each dimension of workplace organization is positively related to the provision of apprenticeships. An insignificant relationship between ' $\Delta$ _hierarchical_levels' and 'job_rotation', respectively, and apprenticeship training would not be surprising. In case of

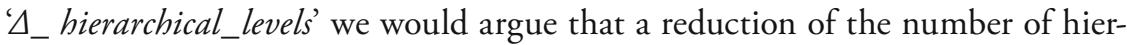
archical layers is an organizational change taking place at the level of the firm 
as a whole, whereas decisions on apprenticeship training are primarily related to the needs of the 'shop floor'; the two decisions may thus hardly be correlated. Job rotation often is a measure implemented by the management for maintaining work motivation among low skilled workers (assembly-line workers, etc.); in this case, 'job_rotation' would not be correlated with apprenticeship training or may even show a negative sign. Teamwork might be a very different matter. We presume that working in teams is an organizational arrangement that is wellsuited for integrating apprentices, since team leaders and experienced co-workers are on the spot for supporting work-based training (positive sign of variable 'team_work'). A high degree of decentralization of decision-making at the workplace ('decentralization'), at first sight, also may be expected to be conducive to apprenticeship training. However, depending on the hierarchical level at which it is decided on hiring apprentices, the training propensity may differ. On the one hand side, one could argue that employees at low hierarchical levels have quite a weak preference for taking on apprentices because this task reduces their own productivity (and thus the wage) as they have to use part of their working time for training apprentices. On the other hand, if decisions on the provision of training are made at a relatively high hierarchical level to guarantee a longterm strategic view on the role of apprenticeship training, the preferences of the employees at the bottom of the hierarchy may be overridden (in this case the skilled workers which are responsible for training apprentices might get specifically paid for this task (and not only for their "immediate" productivity)). One also could argue that a work environment characterized by high autonomy and personal responsibility is very demanding and therefore not a suitable ambit for training apprentices. Similar arguments may apply to ' $\_$delegation' ('degree of delegation of competencies increased'). In sum, though we still expect a positive sign for the variables 'decentralization' and ' $\Delta$ _delegation', reflecting the general hypothesis of a positive effect of workplace organization on training propensity, we do not rule out that these two elements of workplace organization are not (or even negatively) correlated with apprenticeship training. The reasoning on possible effects of the various aspects of workplace organization implies that, in accordance with $\mathrm{H} 3 \mathrm{~b}$, it is very likely that only part of the considered organizational aspects is positively related to the provision of apprenticeships.

\section{Complementarities}

To analyze how the combination of the three constituent elements of the 'new firm paradigm' affects apprenticeship training, we also include interaction terms of human capital, ICT intensity and workplace organization. We expect that 
intensive use of more than one of the three elements increases the effect of the single variables.

H4: The interaction terms related to the summary measures of human capital, ICT and workplace organization are positively related to the provision of apprenticeship training.

\section{Control Variables}

To avoid biased estimates for the core variables of the new firm model, we control for the impact of some specific firm characteristics (wage costs, firm size, foreign/domestic ownership) and include a series of dummy variables that control for effects not explicitly captured by the model.

Firstly, high wages per employee ('labor_costs') are negatively related to a firm's overall demand for labor and, other things being equal, to its need for qualified workers. Consequently, the variable 'labor_costs' is negatively correlated with the provision of apprenticeship training.

Secondly, in accordance with the bulk of empirical studies, we expect that firm size (six firm size dummy variables 'size_d') is positively correlated with the provision of apprenticeship training. Economies of scale in providing in-house training (availability of specialized instructors, specific training facilities, etc.) as well as some monopsony power on the (local) labor market and the existence of internal labor markets (both involving higher retention rates) are probably the most important reasons for the positive correlation of training provision and firm size.

Thirdly, we expect that foreign-owned companies (variable 'foreign_owned') less often provide apprenticeship training than domestic ones, since they usually are less familiar with the Swiss apprenticeship system and/or prefer to rely on 'modes of training' taken over from their home-country.

Finally, we include dummy variables for a firm's affiliation to specific regions and industries as well as a time dummy. These variables should control for effects not explicitly captured by the model. The time dummy 'year_2005' may reflect, in addition to time-varying firm heterogeneity, macroeconomic developments or changes in training policy in the period 2000-2005. The location of a firm, represented by six region dummies ('region_d'), should capture regional differences with respect to the institutional arrangements of apprenticeship training, the size and functioning of the regional labor market, the quality of the regional education system, etc. Besides, a firm's product market environment in terms of demand prospects, market structure and intensity of price and non-price competition may influence training activities (GERsBACH and SCHMUtzler, 2012). For 
example, favorable demand prospects for a firm's products should be positively related to its willingness to offer apprenticeships. We assume that such marketrelated variables, which, for data limitations, cannot be explicitly included in our model, are to a large extent industry-specific; hence, they are captured (in addition to other unspecified influences) by 27 dummies controlling for industry affiliation ('industry_d'). Furthermore, these variables should also capture effects of industry specific input prices that are not considered by other model variables.

So far the cost side of training provision has not been considered explicitly. Training costs vary among firms, in the first place, because of differences with regard to technological requirements (reflecting, for example, physical capital and ICT intensity), the structure of the local labor market for trainees and skilled workers (market power of local firms, regulations, etc.), the institutional framework for apprenticeship and other vocational training as well as for general education at the upper-secondary level, etc. We expect that such variations, to a large extent, are industry-specific ${ }^{4}$ and/or region-specific. Therefore we assume that the costs of training, as far as not yet captured explicitly by the variables representing the use of ICT, are approximately captured by region and industry dummies.

\section{Data}

The data used in this study were collected in the course of two surveys among Swiss companies conducted in 2000 and 2005, respectively. Both surveys were based on a disproportionately stratified random sample of firms covering the business sector (28 industries) and three firm size classes with a cut-off point of 20 employees. We deliberately did not collect data from smaller companies as at least some of the organizational features we are interested in (e.g. 'flattening hierarchical structures') are not relevant for most of them. The two surveys yielded data for 1688 and 1803 firms, respectively, representing response rates of $39.9 \%$ and $36.8 \%$. The data were merged to a data set of 3491 observations. The final sample used for model estimation was somewhat smaller (3005 observations) due

4 In Switzerland, regulation of vocational training is influenced to a significant extent by employer-employee agreements at industry level.

5 The cut-off point of 20 employees for the two samples underlying the surveys of the years 2000 and 2005 has been determined according to the data reported in the Census of Enterprises of 1998 and 2001 respectively. Since, in some companies, the actual number of employees was lower at the time the surveys were carried out in comparison with the data from the preceding census, our data set also contains some firms with less than 20 employees ( $2.4 \%$ of all firms). 
to missing values for one or more variables. As there is a large time lag between the two surveys (five years), only $18 \%$ of the firms replied to both surveys, meaning that the panel is highly unbalanced (what, as shown in the next section, is not without consequences for the choice of the econometric method used for model estimation). $76 \%$ of the firms contained in the final sample provided apprenticeship training, with an average number of apprentices of nearly 2 . In most cases, the means of the variables used in model estimation are quite similar for the two cross-sections (see the descriptive statistics in Table A.1). ${ }^{6}$

The two questionnaires, downloadable from www.kof.ethz.ch, contain questions about the adoption of several ICT technologies (Internet, intranet, extranet, etc.) and the intra-firm diffusion of some of these elements, the use of new organizational practices (team-work, job rotation, employees' involvement in decisionmaking, etc.) and the employees' degrees of general and vocational education. The two surveys also served to collect information on some financial variables and basic structural characteristics of firms.

\section{Econometric Procedure}

As mentioned in the introductory section, we seek to explain, firstly, a firm's training propensity indicating whether a firm does or does not provide apprenticeship training, and, secondly, training intensity reflecting the extent of a firm's involvement in training, measured as the total number of apprentices. As theory does not offer specific explanations for training propensity and training intensity, we use the same set of independent variables in the two empirical models.

In case of the binary dependent variable 'training_propensity', estimating probit regressions is an adequate procedure. To take into consideration firm heterogeneity we use random-effects models. Likelihood-ratio tests showed that pooled probit models are not appropriate. However, pooled and random-effects model yield more or less the same results. We could not estimate fixed-effects models (nor estimate the model in differences) for two reasons; firstly, because of the very limited number of firms replying to the survey in both years, and, secondly, as the dependent variable 'training_propensity' does not much vary over time.

6 The training propensity of the firms of our sample is substantially higher than that of all firms of the Swiss economy (less than $20 \%$ according to official statistics). As the main goal of this paper is to analyze the link between the three core elements of the new firm paradigm and the provision of apprenticeship training it is not necessary to include all Swiss companies. But it is obvious that the results only apply to the firms with 20 and more employees. 
Random-effects regression is thus the preferred method. Furthermore, for nonlinear models we present the average marginal effects of the estimates as this allows us to better interpret the results, e.g. of the interaction terms.

The quantitative dependent variable 'training_intensity' only refers to firms actually providing apprenticeship training. Consequently, selectivity bias may be a problem. We estimate a two-stage Heckman selection model to detect a potential bias (Heckman, 1979). As shown in Table A.3, the intensity equation of the Heckman model is specified in the same way as our main model for 'training intensity' shown in Table 3. The same set of explanatory variables is included in the selection equation, with the exception of the additional identifying variable 'industry_wage_individual_performance' (for definition see Table 1) that is used to make sure that the estimated coefficients are reliable (see WooldRIDGE, 2002a). This instrument is a 3 -digit industry average ${ }^{7}$ of a variable that measures whether the variation of the wage level within a firm primarily depends on the individual performance of the employees. In line with CASSIMAN and VeugeLERS (2002), we assume that this industry variable picks-up the effect of unobserved industry-specific attributes that contribute to the potential endogenous firm-specific variables (see Cassiman and Veugelers, 2002, p. 1174). Accordingly, it can be assumed that the instrument is uncorrelated with the error term. Furthermore, this variable should be a good instrument as it is expected to affect selection but not training intensity. As part of the training of apprentices takes place at external vocational schools, the productivity of apprentices is lower than that of most other employees. Performance-related wages allow firms to adjust the wages of their employees according to their productivity. Consequently, firms with performance-linked wage payment should be more willing to engage in apprenticeship training than firms that cannot adjust their wages, i.e. we expect a positive effect of performance related wages on training propensity. However, this does not hold with respect to the number of apprentices (training intensity) as we expect that the composition of the workforce primarily depends on the substitutability of the different types of employees. A firm will only engage a large number of apprentices if it has enough tasks that can be done by apprentices, the wages it has to pay for them are of secondary importance. The hypothesized relationship can also be observed in the data. The effect of the variable 'industry_wage_individual_performance' is statistically significant positive in the training propensity

7 The industries are defined according to the NACE classification. If the number of observations of a specific 3-digit industry is lower than ten, we used the average score at the NACE two-digit level, excluding the value of the observation itself in order to ensure the exogeneity of these variables. 
equation but insignificant in the training intensity model. As the mills ratio is statistically insignificant at the $10 \%$-level, there is no evidence for a selection bias. ${ }^{8}$

To consider firm heterogeneity we estimate for 'training_intensity' (as in case of 'training propensity') random-effects models, which, according to Lagrangemultiplier tests, are more appropriate than pooled models. Since our panel is highly unbalanced (see Section 3) the number of observations that may be used for estimating fixed-effects models is by far lower than in case of random-effects models. In view of the small size of the sample of the balanced panel it is not surprising that F-statistics are statistically insignificant indicating low model quality. Moreover, sample selection would be a serious problem when estimating a fixedeffects model. ${ }^{9}$ We thus conclude that random-effects regression is the appropriate method to estimate the training intensity model. ${ }^{10}$

Due to multicollinearity we had to perform separate estimates for the variables representing the disaggregated measures of ICT (see the correlation matrix in Table A.2). Furthermore, we tested the impact of disaggregated measures of workplace organization and interaction terms separately in the training intensity models.

A further potential problem is endogeneity, e.g., as we only partially account for training costs. Endogeneity would imply inconsistent estimations. However, as the main objective of a firm is to produce and sell goods and/or services rather than to provide apprenticeship training, primarily economic objectives and not a firm's training decisions should determine the structure of a firm. Therefore, the main results dealing with the impact of human capital, ICT endowment and workplace organization on training decisions should, at least, not be affected by reverse causality. Furthermore, endogeneity should be of little relevance, as we control in our models for different other factors that may affect apprenticeship training such as firm size or industry affiliation.

Nevertheless we test for endogeneity by applying the Rivers-Vuong-Test (WoOldRIDGe, 2002b, p. 483) based on the null hypothesis that the core variables of our model are exogenous. In a first stage, we estimate instrument equations separately for each of three aggregate variables describing the 'new firm

8 In the same way as the main model presented in Table A.3 we also tested the other models of Table 3 for selection bias. In all cases there is no evidence for a selection bias.

9 As the sample which could be used for estimating fixed-effects models is very small, it is plausible that the poor model quality is, in the first place, due to the reduction of the sample size rather than to methodological differences.

10 The fact that the panel is highly unbalanced also makes it impossible to estimating the model in differences. 
Table 2: Estimates of the Propensity of Apprenticeship Training (Average Marginal Effects)

\begin{tabular}{|c|c|c|c|c|c|c|c|}
\hline \multirow[t]{2}{*}{ Explanatory variables } & \multicolumn{7}{|c|}{ Random-effects probit } \\
\hline & (1) & (2) & (3) & (4) & (5) & (6) & (7) \\
\hline \multicolumn{8}{|l|}{ Human capital } \\
\hline tertiary_share & $\begin{array}{l}0.010^{* * *} \\
(0.003)\end{array}$ & $\begin{array}{c}0.006^{*} \\
(0.003)\end{array}$ & & & $\begin{array}{l}0.011^{* * *} \\
(0.003)\end{array}$ & $\begin{array}{l}0.010^{* * *} \\
(0.003)\end{array}$ & $\begin{array}{l}0.010^{* * *} \\
(0.003)\end{array}$ \\
\hline tertiary_d1 & & & $\begin{array}{l}0.095^{* * *} \\
(0.030)\end{array}$ & & & & \\
\hline tertiary_d2 & & & $\begin{array}{l}0.126^{* * *} \\
(0.028)\end{array}$ & & & & \\
\hline tertiary_d3 & & & $\begin{array}{l}0.126^{* * *} \\
(0.030)\end{array}$ & & & & \\
\hline tertiary_d4 & & & $\begin{array}{l}0.123^{* * *} \\
(0.034)\end{array}$ & & & & \\
\hline tertiary_d5 & & & $\begin{array}{c}-0.003 \\
(0.038)\end{array}$ & & & & \\
\hline university_tertiary & & & & $\begin{array}{c}-0.006 \\
(0.005)\end{array}$ & & & \\
\hline $\begin{array}{l}\text { non-university_ } \\
\text { tertiary }\end{array}$ & & & & $\begin{array}{l}0.022^{* * *} \\
(0.006)\end{array}$ & & & \\
\hline \multicolumn{8}{|l|}{ ICT usage } \\
\hline ICT_total & $\begin{array}{l}0.013^{* * *} \\
(0.004)\end{array}$ & $\begin{array}{l}0.016^{* * *} \\
(0.005)\end{array}$ & $\begin{array}{l}0.015^{* * *} \\
(0.004)\end{array}$ & $\begin{array}{l}0.014^{* * *} \\
(0.004)\end{array}$ & & & \\
\hline intranet_use_d1 & & & & & $\begin{array}{l}0.051^{* *} \\
(0.021)\end{array}$ & & \\
\hline intranet_use_d2 & & & & & $\begin{array}{c}0.015 \\
(0.025)\end{array}$ & & \\
\hline Internet_variety & & & & & & $\begin{array}{l}0.015^{* * *} \\
(0.005)\end{array}$ & \\
\hline ICT_infrustructure & & & & & & & $\begin{array}{c}0.021^{*} \\
(0.012)\end{array}$ \\
\hline \multicolumn{8}{|l|}{ Work organization } \\
\hline WO_total & $\begin{array}{c}-0.006^{*} \\
(0.003)\end{array}$ & $\begin{array}{c}-0.006^{*} \\
(0.004)\end{array}$ & $\begin{array}{c}-0.005 \\
(0.003)\end{array}$ & $\begin{array}{c}-0.006^{*} \\
(0.003)\end{array}$ & & & \\
\hline$\Delta \_$hierarchical_levels & & & & & $\begin{array}{c}-0.038 \\
(0.025)\end{array}$ & $\begin{array}{c}-0.038 \\
(0.025)\end{array}$ & $\begin{array}{c}-0.034 \\
(0.025)\end{array}$ \\
\hline$\Delta \_$delegation & & & & & $\begin{array}{c}-0.008 \\
(0.017)\end{array}$ & $\begin{array}{c}-0.008 \\
(0.017)\end{array}$ & $\begin{array}{c}-0.007 \\
(0.017)\end{array}$ \\
\hline decentralization & & & & & $\begin{array}{l}-0.038^{* * *} \\
(0.013)\end{array}$ & $\begin{array}{c}-0.037^{* * *} \\
(0.013)\end{array}$ & $\begin{array}{c}-0.038^{* * *} \\
(0.013)\end{array}$ \\
\hline job_rotation & & & & & $\begin{array}{c}-0.005 \\
(0.007)\end{array}$ & $\begin{array}{c}-0.006 \\
(0.007)\end{array}$ & $\begin{array}{c}-0.005 \\
(0.007)\end{array}$ \\
\hline
\end{tabular}


Table 2 continued

\begin{tabular}{|c|c|c|c|c|c|c|c|}
\hline \multirow[t]{2}{*}{ Explanatory variables } & \multicolumn{7}{|c|}{ Random-effects probit } \\
\hline & (1) & (2) & (3) & $(4)$ & (5) & (6) & (7) \\
\hline team_work & & & & & $\begin{array}{l}0.012^{* *} \\
(0.005)\end{array}$ & $\begin{array}{l}0.011^{* *} \\
(0.005)\end{array}$ & $\begin{array}{l}0.012^{* *} \\
(0.005)\end{array}$ \\
\hline \multicolumn{8}{|l|}{ Complementarity } \\
\hline $\mathrm{HC} \times \mathrm{ICT}$ & & $\begin{array}{c}-0.002^{*} \\
(0.001)\end{array}$ & & & & & \\
\hline $\mathrm{HC} \times \mathrm{WO}$ & & $\begin{array}{c}0.000 \\
(0.001)\end{array}$ & & & & & \\
\hline $\mathrm{ICT} \times \mathrm{WO}$ & & $\begin{array}{c}-0.001 \\
(0.001)\end{array}$ & & & & & \\
\hline \multicolumn{8}{|l|}{ Control variables } \\
\hline labor_costs & $\begin{array}{c}-0.028 \\
(0.028)\end{array}$ & $\begin{array}{c}-0.022 \\
(0.028)\end{array}$ & $\begin{array}{c}-0.015 \\
(0.028)\end{array}$ & $\begin{array}{c}-0.026 \\
(0.028)\end{array}$ & $\begin{array}{c}-0.023 \\
(0.028)\end{array}$ & $\begin{array}{c}-0.024 \\
(0.028)\end{array}$ & $\begin{array}{c}-0.023 \\
(0.028)\end{array}$ \\
\hline foreign_owned & $\begin{array}{c}-0.115^{\text {*** }} \\
(0.024)\end{array}$ & $\begin{array}{c}-0.115^{* * *} \\
(0.024)\end{array}$ & $\begin{array}{c}-0.107^{* * *} \\
(0.024)\end{array}$ & $\begin{array}{c}-0.118^{* * *} \\
(0.024)\end{array}$ & $\begin{array}{l}-0.109^{* * *} \\
(0.024)\end{array}$ & $\begin{array}{c}-0.108^{* * *} \\
(0.024)\end{array}$ & $\begin{array}{c}-0.112^{\text {*** }} \\
(0.024)\end{array}$ \\
\hline size_d1 & $\begin{array}{c}0.075 \\
(0.051)\end{array}$ & $\begin{array}{c}0.078 \\
(0.051)\end{array}$ & $\begin{array}{c}0.077 \\
(0.051)\end{array}$ & $\begin{array}{c}0.075 \\
(0.051)\end{array}$ & $\begin{array}{c}0.064 \\
(0.051)\end{array}$ & $\begin{array}{c}0.072 \\
(0.051)\end{array}$ & $\begin{array}{c}0.066 \\
(0.051)\end{array}$ \\
\hline size_d2 & $\begin{array}{l}0.197^{* * *} \\
(0.052)\end{array}$ & $\begin{array}{l}0.200^{* * *} \\
(0.051)\end{array}$ & $\begin{array}{l}0.202^{* * *} \\
(0.052)\end{array}$ & $\begin{array}{l}0.202^{* * *} \\
(0.052)\end{array}$ & $\begin{array}{l}0.185^{* * *} \\
(0.051)\end{array}$ & $\begin{array}{l}0.191^{* * *} \\
(0.051)\end{array}$ & $\begin{array}{l}0.188^{* * *} \\
(0.051)\end{array}$ \\
\hline size_d3 & $\begin{array}{l}0.297^{* * *} \\
(0.053)\end{array}$ & $\begin{array}{l}0.299^{* * *} \\
(0.052)\end{array}$ & $\begin{array}{l}0.303^{* * *} \\
(0.052)\end{array}$ & $\begin{array}{l}0.304^{* * *} \\
(0.053)\end{array}$ & $\begin{array}{l}0.287^{* * *} \\
(0.052)\end{array}$ & $\begin{array}{l}0.295^{* * *} \\
(0.052)\end{array}$ & $\begin{array}{l}0.288^{* * * *} \\
(0.052)\end{array}$ \\
\hline size_d4 & $\begin{array}{l}0.429^{* * *} \\
(0.061)\end{array}$ & $\begin{array}{l}0.431^{\text {*** }} \\
(0.061)\end{array}$ & $\begin{array}{l}0.429^{* * *} \\
(0.061)\end{array}$ & $\begin{array}{l}0.438^{* * *} \\
(0.062)\end{array}$ & $\begin{array}{l}0.415^{* * *} \\
(0.061)\end{array}$ & $\begin{array}{l}0.422^{* * *} \\
(0.061)\end{array}$ & $\begin{array}{l}0.422^{* * *} \\
(0.061)\end{array}$ \\
\hline size_d5 & $\begin{array}{l}0.364^{* * *} \\
(0.067)\end{array}$ & $\begin{array}{l}0.370^{* * *} \\
(0.067)\end{array}$ & $\begin{array}{l}0.365^{* * *} \\
(0.066)\end{array}$ & $\begin{array}{l}0.373^{* * *} \\
(0.067)\end{array}$ & $\begin{array}{l}0.355^{* * *} \\
(0.066)\end{array}$ & $\begin{array}{l}0.360^{* * *} \\
(0.067)\end{array}$ & $\begin{array}{l}0.356^{* * *} \\
(0.066)\end{array}$ \\
\hline size_d6 & $\begin{array}{l}0.518^{* * *} \\
(0.079)\end{array}$ & $\begin{array}{l}0.526^{* * *} \\
(0.079)\end{array}$ & $\begin{array}{l}0.524^{* * *} \\
(0.079)\end{array}$ & $\begin{array}{l}0.526^{* * *} \\
(0.079)\end{array}$ & $\begin{array}{l}0.526^{* * *} \\
(0.079)\end{array}$ & $\begin{array}{l}0.522^{* * *} \\
(0.079)\end{array}$ & $\begin{array}{l}0.524^{* * *} \\
(0.079)\end{array}$ \\
\hline year_2005 & $\begin{array}{c}0.027^{*} \\
(0.015)\end{array}$ & $\begin{array}{c}0.027^{*} \\
(0.015)\end{array}$ & $\begin{array}{c}0.024 \\
(0.015)\end{array}$ & $\begin{array}{c}0.028^{*} \\
(0.015)\end{array}$ & $\begin{array}{l}0.030^{* *} \\
(0.015)\end{array}$ & $\begin{array}{l}0.030^{* *} \\
(0.015)\end{array}$ & $\begin{array}{l}0.031^{* *} \\
(0.015)\end{array}$ \\
\hline Region dummies & yes & yes & yes & yes & yes & yes & yes \\
\hline Industry dummies & yes & yes & yes & yes & yes & yes & yes \\
\hline $\mathrm{N}$ & 3005 & 3005 & 3005 & 3005 & 3005 & 3005 & 3005 \\
\hline Wald chi $^{2}$ & $102.19^{* * *}$ & $100.47^{* * *}$ & $107.30^{* * *}$ & $102.47^{* * *}$ & $99.42^{* * *}$ & $100.43^{* * *}$ & $98.26^{* * *}$ \\
\hline Rho & 0.775 & 0.781 & 0.762 & 0.774 & 0.783 & 0.784 & 0.784 \\
\hline LR test of $r h o=0$ & $116.48^{* * *}$ & $117.53^{* * *}$ & $111.49^{* * *}$ & $115.86^{* * *}$ & $119.77^{* * *}$ & $121.76^{* * *}$ & $118.40^{* * *}$ \\
\hline
\end{tabular}

Notes: See Table 1 for the variable definitions; to estimate marginal effects, we fixed the group specific intercept at 0 , but otherwise averaged the marginal effects over the other explanatory variables; standard errors are in brackets under the coefficients; ${ }^{* * *},{ }^{* *},{ }^{*}$ denotes statistical significance at the $1 \%, 5 \%$ and $10 \%$ test level, respectively. 
Table 3: Estimates of the Intensity of Apprenticeship Training

\begin{tabular}{|c|c|c|c|c|c|c|c|}
\hline \multirow[t]{2}{*}{ Explanatory variables } & \multicolumn{7}{|c|}{ Random-effects GLS } \\
\hline & (1) & (2) & (3) & $(4)$ & (5) & (6) & (7) \\
\hline \multicolumn{8}{|l|}{ Human capital } \\
\hline tertiary_share & $\begin{array}{l}0.019^{* *} \\
(0.008)\end{array}$ & $\begin{array}{l}0.022^{* * *} \\
(0.008)\end{array}$ & & & $\begin{array}{l}0.018^{* *} \\
(0.008)\end{array}$ & $\begin{array}{l}0.018^{* *} \\
(0.008)\end{array}$ & $\begin{array}{c}0.018^{* *} \\
(0.008)\end{array}$ \\
\hline tertiary_d1 & & & $\begin{array}{l}0.186^{* *} \\
(0.076)\end{array}$ & & & & \\
\hline tertiary_d2 & & & $\begin{array}{l}0.273^{* * *} \\
(0.070)\end{array}$ & & & & \\
\hline tertiary_d3 & & & $\begin{array}{l}0.400^{* * *} \\
(0.072)\end{array}$ & & & & \\
\hline tertiary_d4 & & & $\begin{array}{l}0.415^{* * *} \\
(0.080)\end{array}$ & & & & \\
\hline tertiary_d5 & & & $\begin{array}{l}0.240^{* *} \\
(0.098)\end{array}$ & & & & \\
\hline university_tertiary & & & & $\begin{array}{c}0.004 \\
(0.011)\end{array}$ & & & \\
\hline $\begin{array}{l}\text { non-university_ } \\
\text { tertiary }\end{array}$ & & & & $\begin{array}{l}0.066^{* * *} \\
(0.016)\end{array}$ & & & \\
\hline \multicolumn{8}{|l|}{ ICT usage } \\
\hline ICT_total & $\begin{array}{c}0.009 \\
(0.009)\end{array}$ & $\begin{array}{c}0.005 \\
(0.010)\end{array}$ & $\begin{array}{c}0.006 \\
(0.009)\end{array}$ & $\begin{array}{c}0.008 \\
(0.010)\end{array}$ & & & \\
\hline intranet_use_d1 & & & & & $\begin{array}{c}0.059 \\
(0.043)\end{array}$ & & \\
\hline intranet_use_d2 & & & & & $\begin{array}{c}0.040 \\
(0.050)\end{array}$ & & \\
\hline Internet_variety & & & & & & $\begin{array}{c}0.005 \\
(0.010)\end{array}$ & \\
\hline ICT_infrustructure & & & & & & & $\begin{array}{c}0.029 \\
(0.027) \\
\end{array}$ \\
\hline \multicolumn{8}{|l|}{ Work organization } \\
\hline WO_total & $\begin{array}{c}0.013^{* *} \\
(0.007)\end{array}$ & $\begin{array}{c}0.014 \\
(0.009)\end{array}$ & $\begin{array}{c}0.011^{*} \\
(0.007)\end{array}$ & $\begin{array}{c}0.012^{*} \\
(0.007)\end{array}$ & & & \\
\hline$\Delta \_$hierarchical_levels & & & & & $\begin{array}{c}0.093^{*} \\
(0.053)\end{array}$ & $\begin{array}{c}0.096^{*} \\
(0.053)\end{array}$ & $\begin{array}{c}0.101^{*} \\
(0.053)\end{array}$ \\
\hline$\Delta \_$delegation & & & & & $\begin{array}{c}0.012 \\
(0.035)\end{array}$ & $\begin{array}{c}0.014 \\
(0.034)\end{array}$ & $\begin{array}{c}0.017 \\
(0.035)\end{array}$ \\
\hline decentralization & & & & & $\begin{array}{c}0.032 \\
(0.027)\end{array}$ & $\begin{array}{c}0.034 \\
(0.027)\end{array}$ & $\begin{array}{c}0.034 \\
(0.027)\end{array}$ \\
\hline job_rotation & & & & & $\begin{array}{c}-0.006 \\
(0.015)\end{array}$ & $\begin{array}{c}-0.006 \\
(0.015)\end{array}$ & $\begin{array}{c}-0.007 \\
(0.015)\end{array}$ \\
\hline team_work & & & & & $\begin{array}{c}0.009 \\
(0.011)\end{array}$ & $\begin{array}{c}0.009 \\
(0.011)\end{array}$ & $\begin{array}{c}0.008 \\
(0.011)\end{array}$ \\
\hline
\end{tabular}


Table 3 continued

\begin{tabular}{|c|c|c|c|c|c|c|c|}
\hline \multirow[t]{2}{*}{ Explanatory variables } & \multicolumn{7}{|c|}{ Random-effects GLS } \\
\hline & (1) & (2) & (3) & (4) & (5) & (6) & (7) \\
\hline \multicolumn{8}{|l|}{ Complementarity } \\
\hline $\mathrm{HC} \times \mathrm{ICT}$ & & $\begin{array}{c}0.003 \\
(0.002)\end{array}$ & & & & & \\
\hline $\mathrm{HC} \times \mathrm{WO}$ & & $\begin{array}{c}-0.001 \\
(0.003)\end{array}$ & & & & & \\
\hline $\mathrm{ICT} \times \mathrm{WO}$ & & $\begin{array}{c}0.006^{*} \\
(0.003)\end{array}$ & & & & & \\
\hline \multicolumn{8}{|l|}{ Control variables } \\
\hline labor_costs & $\begin{array}{c}-0.292^{* * *} \\
(0.064)\end{array}$ & $\begin{array}{c}-0.296^{* * *} \\
(0.065)\end{array}$ & $\begin{array}{c}-0.314^{* * *} \\
(0.064)\end{array}$ & $\begin{array}{c}-0.310^{* * *} \\
(0.064)\end{array}$ & $\begin{array}{c}-0.299^{* * *} \\
(0.065)\end{array}$ & $\begin{array}{c}-0.291^{* * *} \\
(0.065)\end{array}$ & $\begin{array}{c}-0.293^{* * *} \\
(0.065)\end{array}$ \\
\hline foreign_owned & $\begin{array}{c}-0.067 \\
(0.052)\end{array}$ & $\begin{array}{c}-0.068 \\
(0.052)\end{array}$ & $\begin{array}{c}-0.070 \\
(0.052)\end{array}$ & $\begin{array}{c}-0.076 \\
(0.052)\end{array}$ & $\begin{array}{c}-0.056 \\
(0.052)\end{array}$ & $\begin{array}{c}-0.053 \\
(0.052)\end{array}$ & $\begin{array}{c}-0.067 \\
(0.052)\end{array}$ \\
\hline size_d1 & $\begin{array}{l}0.448^{* * *} \\
(0.142)\end{array}$ & $\begin{array}{l}0.443^{* * *} \\
(0.141)\end{array}$ & $\begin{array}{l}0.482^{* * *} \\
(0.139)\end{array}$ & $\begin{array}{l}0.440^{* * *} \\
(0.144)\end{array}$ & $\begin{array}{l}0.447^{* * *} \\
(0.141)\end{array}$ & $\begin{array}{l}0.452^{* * *} \\
(0.140)\end{array}$ & $\begin{array}{l}0.451^{* * *} \\
(0.141)\end{array}$ \\
\hline size_d2 & $\begin{array}{l}0.789^{* * *} \\
(0.144)\end{array}$ & $\begin{array}{l}0.785^{* * *} \\
(0.144)\end{array}$ & $\begin{array}{l}0.840^{* * *} \\
(0.142)\end{array}$ & $\begin{array}{l}0.787^{* * *} \\
(0.147)\end{array}$ & $\begin{array}{l}0.785^{\text {*** }} \\
(0.143)\end{array}$ & $\begin{array}{l}0.793^{* * *} \\
(0.143)\end{array}$ & $\begin{array}{l}0.793^{* * *} \\
(0.143)\end{array}$ \\
\hline size_d3 & $\begin{array}{l}1.432^{* * *} \\
(0.145)\end{array}$ & $\begin{array}{l}1.431^{* * *} \\
(0.145)\end{array}$ & $\begin{array}{l}1.471^{* * *} \\
(0.142)\end{array}$ & $\begin{array}{l}1.421^{* * *} \\
(0.148)\end{array}$ & $\begin{array}{l}1.428^{* * *} \\
(0.144)\end{array}$ & $\begin{array}{l}1.436^{* * *} \\
(0.144)\end{array}$ & $\begin{array}{l}1.430^{* * *} \\
(0.144)\end{array}$ \\
\hline size_d4 & $\begin{array}{l}2.115^{* * *} \\
(0.149)\end{array}$ & $\begin{array}{l}2.114^{* * *} \\
(0.149)\end{array}$ & $\begin{array}{l}2.149^{* * *} \\
(0.146)\end{array}$ & $\begin{array}{l}2.104^{* * *} \\
(0.152)\end{array}$ & $\begin{array}{l}2.099^{* * *} \\
(0.149)\end{array}$ & $\begin{array}{l}2.112^{* * *} \\
(0.148)\end{array}$ & $\begin{array}{l}2.112^{* * *} \\
(0.148)\end{array}$ \\
\hline size_d5 & $\begin{array}{l}2.794^{* * *} \\
(0.160)\end{array}$ & $\begin{array}{l}2.785^{* * *} \\
(0.160)\end{array}$ & $\begin{array}{l}2.823^{* * *} \\
(0.157)\end{array}$ & $\begin{array}{l}2.780^{* * *} \\
(0.162)\end{array}$ & $\begin{array}{l}2.789^{* * *} \\
(0.160)\end{array}$ & $\begin{array}{l}2.799^{* * *} \\
(0.159)\end{array}$ & $\begin{array}{l}2.797^{* * *} \\
(0.159)\end{array}$ \\
\hline size_d6 & $\begin{array}{l}4.074^{* * *} \\
(0.181)\end{array}$ & $\begin{array}{l}4.056^{* * *} \\
(0.181)\end{array}$ & $\begin{array}{l}4.114^{* * *} \\
(0.176)\end{array}$ & $\begin{array}{l}4.060^{* * *} \\
(0.183)\end{array}$ & $\begin{array}{l}4.080^{* * *} \\
(0.180)\end{array}$ & $\begin{array}{l}4.093^{* * *} \\
(0.179)\end{array}$ & $\begin{array}{l}4.077^{* * *} \\
(0.180)\end{array}$ \\
\hline year_2005 & $\begin{array}{c}0.049^{*} \\
(0.029)\end{array}$ & $\begin{array}{c}0.050^{*} \\
(0.029)\end{array}$ & $\begin{array}{c}0.040 \\
(0.029)\end{array}$ & $\begin{array}{c}0.045 \\
(0.029)\end{array}$ & $\begin{array}{c}0.048 \\
(0.030)\end{array}$ & $\begin{array}{c}0.050^{*} \\
(0.030)\end{array}$ & $\begin{array}{c}0.052^{*} \\
(0.030)\end{array}$ \\
\hline constant & $\begin{array}{l}2.438^{* * *} \\
(0.748)\end{array}$ & $\begin{array}{l}2.455^{\text {*** }} \\
(0.750)\end{array}$ & $\begin{array}{l}2.516^{* * *} \\
(0.737)\end{array}$ & $\begin{array}{l}2.594^{* * *} \\
(0.748)\end{array}$ & $\begin{array}{l}2.406^{* * *} \\
(0.757)\end{array}$ & $\begin{array}{l}2.295^{* * *} \\
(0.746)\end{array}$ & $\begin{array}{l}2.227^{* * *} \\
(0.754)\end{array}$ \\
\hline Region dummies & yes & yes & yes & yes & yes & yes & yes \\
\hline Industry dummies & yes & yes & yes & yes & yes & yes & yes \\
\hline $\mathrm{N}$ & 2274 & 2274 & 2274 & 2274 & 2274 & 2274 & 2274 \\
\hline Wald chi ${ }^{2}$ & $2375.56^{* * *}$ & $2432.19^{* * *}$ & $2466.27^{* * *}$ & $2388.57^{* * *}$ & $2403.55^{* * *}$ & $2408.67^{* * *}$ & $2380.56^{* * *}$ \\
\hline $\mathrm{R}^{2}$ within & 0.167 & 0.165 & 0.179 & 0.175 & 0.167 & 0.171 & 0.167 \\
\hline Rho & 0.597 & 0.597 & 0.599 & 0.601 & 0.595 & 0.596 & 0.594 \\
\hline LM test & $130.55^{* * *}$ & $129.28^{* * *}$ & $121.60^{* * *}$ & $127.74^{* * *}$ & $128.80^{* * *}$ & $129.25^{* * *}$ & $128.62^{* * *}$ \\
\hline
\end{tabular}

Notes: See Table 2 for the variable definitions; the significance of the parameters is indicated with ***, ${ }^{* *}$ and ${ }^{*}$ resp. representing the $1 \%$-, 5\%- and 10\%-level, respectively. Heteroskedasticity-robust standard errors are in brackets under the coefficients (White procedure). 
paradigm'. We use industry averages as instruments (in the same way as in the Heckman model). All instruments in these equations fulfill the required conditions: they are correlated with the dependent variable in the instrument equation but uncorrelated with the dependent variable in the structural equation (training equation) and they are not correlated with the residuals of the endogenized training equation (for details of measurement see Table 1). In line with CAssiMAN and Veugelers (2002), we assume that each of these industry variables picks-up the effect of unobserved industry-specific attributes that contribute to the potential endogenous firm-specific variables (see Cassiman and Veugelers, 2002 , p. 1174). In a second stage, we include the residuals of the first stage in our training equation. To correct the standard errors of the estimated parameters we use bootstrapping. Under $\mathrm{H}_{0}$ the residuals of the instrument equations and the residuals of the second stage equations are uncorrelated.

The tests for endogeneity in the training propensity and the training intensity equation refer to the summary measures of human capital (variable 'tertiary share'), ICT (variable 'ICT_total') and workplace organization (variable 'WO_ total'). In case of random-effects probit models, such a test is very time consuming; therefore we perform the test without correcting for firm heterogeneity. Using our instruments we throughout cannot reject the null hypothesis of exogenous variables (see Table A.4). Therefore we conclude that the three core elements of the 'new firm paradigm' affect apprenticeship training directly and there is no problem with reverse causality.

\section{Empirical Results}

\subsection{Training Propensity}

Table 2 shows the results with training propensity as dependent variable. We primarily are interested in the influence on training propensity exerted by the variables representing the core dimensions of the new firm paradigm, i.e. human capital, ICT and workplace organization. Columns (1) and (2) refer to estimates where these core elements are specified as aggregate variables, with column (2) including complementarity effects. To better understand these main results, columns (3) to (7) contain the findings based on a more disaggregated specification of human capital, ICT and workplace organization.

Firstly, the results with respect to human capital are fully in line with a priori expectations; hypothesis $\mathrm{H} 1$ is thus confirmed. Firms with a high share of employees with tertiary education are significantly more likely to offer apprenticeships. 
Interestingly, the positive effect of tertiary education is increasing only up to a share of 6-13\% (dummy variable 'tertiary_d2') and becomes insignificant beyond the threshold of $43 \%$ ('tertiary_d5'). Hence, in case of very high levels of human capital input, the probability of apprenticeship training is low (i.e. not higher than for the reference group containing firms with a share of employees with tertiary qualifications below 3\%. In line with this result, we furthermore find that the significant positive effect for tertiary educated employees comes from non-university tertiary educated employees rather than from employees with a university degree. Accordingly, we find non-linear effects for both, the intensity and the level of tertiary level education.

The second element of the new system of production, i.e. the usage of ICT, also is positively related to training propensity what again matches the a priori expectations as stated in hypothesis $\mathrm{H} 2$. This holds true independently of whether ICT is specified as an aggregate variable ('ICT_total') or captured by three disaggregated measures. Training propensity is particularly high in firms with a broad ICT infrastructure (variable 'ICT_infrastructure') and a high variety of applications of the Internet use ('Internet_variety'). The influence of the intrafirm diffusion of the intranet ('intranet_use_d') also is positive but, interestingly, the effect is not linear. We find a positive sign only at a medium intensity of intranet use, i.e. firms with regular intranet users in the range of $21 \%$ to $60 \%$ ('intranet_use_d1').

The third element - the redesign of workplace organization - is correlated with training propensity to a much lower extent than ICT usage, reflecting the fact that only some of the dimensions of workplace organization are correlated with training propensity. Working in a team (variable 'team_work'), as hypothesized, is a favorable environment for in-house vocational training. The data also confirm the argument that flattening of hierarchies (' $\Delta$ _hierarchical_levels') and making use of job rotation ('job_rotation)' do not influence training propensity. The negative sign we find for the degree of decentralization of competencies ('decentralization') and the insignificant coefficient of ' $\Delta$ _delegation' are not in line with the overall hypothesis of a positive effect of workplace organization on training propensity. However, we also have put forward some arguments in favor of a negative sign for 'decentralization' ('insufficient incentive at the shop floor to instructing apprentices'; 'high autonomy of performing work tasks as a too demanding work environment for apprentices'), and similar arguments may hold true in case of ' $\Delta$ _delegation'. Given the opposite effects of the individual elements of workplace organization, it is not surprising that the impact of aggregate workplace organization ('WO_total') on training propensity is weak (with the negative effects slightly outweighing the positive ones). In conclusion, we 
do not find evidence for hypothesis $\mathrm{H} 3 \mathrm{a}$ (positive overall effect of workplace organization). In contrast, hypothesis $\mathrm{H} 3 \mathrm{~b}$ is largely confirmed as the impact of the five organizational dimensions is different and more or less in line with our considerations in Section 2.

Fourthly, theory posits that the new firm model is characterized by complementarities between human capital, ICT and workplace organization, which should have an additional positive effect on the demand for skilled labor. Therefore, although the evidence for such effects is not overwhelming (see Section 1), we hypothesized that the complementarities positively affect training propensity (hypothesis H4). However, this proposition is not corroborated by our empirical estimates. The interaction term based on the aggregate measures of ICT and workplace organization (ICT*WO) as well as on human capital and workplace organization ( $\mathrm{HC}^{*} \mathrm{WO}$ ) are statistically insignificant (see column 2 in Table 2). We even get a negative effect of the interaction of human capital with ICT intensity (HC*ICT). Hence, the combination of intensive use of ICT and a high share of employees with tertiary qualifications reduces the propensity of apprenticeship training. This negative interaction effect partially reflects the results we got for the dummies 'tertiary_d', 'university_tertiary' and 'intranet_use_d'. These show that a very high share of employees holding tertiary degrees and a high intensity of intranet use do not positively correlate with the firms' training propensity, whereas at an intermediate level of the two variables both effects are positive. Hence, the finding that the interaction effect $\mathrm{HC}^{*} \mathrm{ICT}$ is negative, may be attributed to the behavior of the segment of firms having implemented the new firm model to a very high degree.

The effects of the control variables are in line with the expectations. An exception is the variable (average) 'labor_costs' which, contrary to the expectations, does not negatively correlate with training propensity. ${ }^{11}$ As expected, training propensity increases with firm size more or less monotonically (dummy variables 'size_d'). Foreign companies ('foreign_owned') are less involved in apprenticeship training than domestic ones, supporting the presumption that foreign enterprises are less familiar with the Swiss apprenticeship system. We also find a positive time effect for the year 2005, probably reflecting policy measures (campaigning among firms to offering apprenticeships, etc.) taken in the aftermath

11 The positive correlation between 'labor costs' (wage bill per employee) and human capital use (see Table A.2 in the appendix) may contribute to this result. Another reason may be the positive relationship between the wage bill per employee and capital income per employee ('profitability') which results from profit sharing among employers and employees. 
of the economic downturn of 2001/03. Finally, the dummies reflecting region and industry effects are statistically significant.

Summing up, the empirical results for the model explaining a firm's propensity to provide apprenticeship training supports three out of the five hypotheses we put forward in Section 2. There is strong evidence for a positive relationship with training propensity in case of two of the three core elements of the new firm paradigm, that is human capital (hypothesis H1) and ICT (Hypothesis H2: summary and differentiated measures). Only very intensive use of these two elements discourages firms from providing apprenticeship training. The effect of workplace organization is significant just for some of the organizational dimensions included in the model, with the effects more or less in line with our considerations in Section 2 (hypothesis H3b). Finally, we do not find evidence for positive interaction effects. On balance, we conclude that a change towards the new firm paradigm goes along with an increasing propensity of firms to provide apprenticeships.

\subsection{Training Intensity}

In accordance with hypothesis $\mathrm{H} 1$, human capital positively affects the intensity of apprenticeship training ('tertiary_share'). Again, the effect of human capital ('tertiary_d') on training does increase up to a certain threshold (see Table 3). We find a pattern which is quite similar to that we found in case of training propensity. More specifically, firms with a share of employees with tertiary qualifications of more than $3 \%$ show significantly higher training intensities than the reference group (below 3\%). A new result is that firms with a share of highly qualified employees in the range of 3\% to $13 \%$ ('tertiary_d1 and $\mathrm{d} 2$ ') have a significantly lower training intensity than firms with a share in the range of $13 \%$ to $43 \%$ ('tertiary_d3 and d4'), but this is not the case anymore beyond the threshold of 43\% ('tertiary_d5'). The impact of human capital on training intensity is thus non-linear; it is stepwise increasing up to a share of $43 \%$ and is decreasing beyond this threshold value. Furthermore, we again find that the significant positive effect for tertiary educated employees comes from non-university tertiary educated employees rather than from employees with a university degree.

The redesign of the workplace organization measured at the aggregate level ('WO_total'), in line with hypothesis $\mathrm{H} 3 \mathrm{a}$, positively affects a firm's training intensity, whereas in case of training propensity we did not find such an effect. However, it is difficult to identify a single driver of this effect on a more disaggregated level. With the exception of job rotation ('job_rotation') all measures of new workplace organization show a positive sign, but only in case of a reduction 
of the hierarchical levels (' $\Delta$ _hierarchical_levels') the effect on a firm's training intensity is statistically significant. Hypothesis $\mathrm{H} 3 \mathrm{~b}$ is thus supported but the evidence is not overwhelming. One may ask why the sign of the aggregated effect of new workplace organization differs for training intensity (positive) and training propensity (negative). A reason for the negative effect in case of training propensity may be the high fixed costs of apprenticeship training in a work environment with a high degree of new workplace organization. Once the (initial) investment has been made, it pays off to increase the number of apprentices; hence the impact on training intensity is positive. Furthermore, it is surprising that ' $\Delta$ _hierarchical_levels' does affect training intensity but not training propensity. A reason for this result may be that, in contrast to training propensity, intensive apprenticeship training is not a decision at the shop-floor and, hence, is more directly correlated with organizational changes taking place at the level of the firm as a whole.

ICT does not contribute to explaining training intensity, irrespective of the way it is measured ('ICT_total' vs. differentiated ICT variables). Hypothesis H2 is thus not confirmed. This result, which is in contrast to that for training propensity, has to be qualified as we identify an indirect effect of ICT. The interaction term of ICT and workplace organization (ICT*WO) is significantly positive (see column 3 of Table 3). Companies combining an intensive use of ICT with a redesign of workplace organization exhibit a higher training intensity than other firms. Hence, there is some evidence for the existence of complementarities in explaining the apprenticeship training intensity what is in line with hypothesis $\mathrm{H} 4$.

The majority of the explanatory variables not related to the new firm paradigm show the expected influence on training intensity. As expected, the impact of 'labor_costs' is significantly negative. The firm-size effect, as expected, does not differ among the two training variables; the size effect monotonically increases both for the training propensity and training intensity. The impact of foreign ownership ('foreign_owned') is not statistically significant anymore, implying that foreign firms, once familiar with the Swiss apprenticeship system, behave in training matters like domestic firms. The region and industry dummies again are statistically significant. Finally, we again get a positive time effect (variable 'year_2005').

Summing up, we find evidence for a positive impact on training intensity for two of the three categories of variables representing the new firm paradigm, i.e. human capital intensity (hypothesis H1) and workplace organization (hypotheses $\mathrm{H} 3 \mathrm{a}$ and $\mathrm{H} 3 \mathrm{~b}$ ). This is not the case for ICT if taken separately (direct effect). However, the combined effect of ICT and workplace organization (interaction term) is positive, pointing to the importance of complementarities in explaining 
the extent of apprenticeship training (hypothesis H4). Although not all hypotheses are confirmed, one may conclude that a transition towards the new firm paradigm is accompanied by an increasing intensity of apprenticeship training in firms providing this type of training.

\section{Comparison with Existing Empirical Literature}

How do the findings with regard to the core variables of our model compare to the results of previous econometric work? The few studies taking account of ICT yielded mixed results. BeCKMANn $(2002,2008)$, based on a very rough measure of IT investments, got a positive effect on training propensity and intensity for a cross-section of German firms, whereas we did so only in case of training propensity. Arvanitis and StUCKi (2011) found some weak evidence for a negative influence of the usage of Internet and intranet on training propensity based on a cohort of Swiss start-up firms. In view of the different measurement of ICT (investment in IT vs. several characteristics of ICT) and of specific sample characteristics (new vs. established firms) a comparison of the results of these studies with our findings is not very meaningful.

It is even more difficult to compare the results with respect to the impact of workplace organization on the provision of apprenticeship training, since - to our knowledge - this paper is the only one that includes organizational variables in an econometric analysis of the topic. However, we notice that the results of this study are more or less in line with Finegold and WAGNER (2002) who, based on a case study for the German banking sector, argue that hiring apprentices becomes more attractive when work organization gets more flexible and, in particular, when the incidence of teamwork increases.

Human capital is used as a variable to explaining why and to what extent firms offer apprenticeship places in quite a few studies (see, e.g., Arvanitis, 2008; Beckmann, 2002, 2008; Franz et al., 2000). In accordance with our results, these authors throughout find a positive effect of qualified as compared to unqualified labor.

\section{Summary and Conclusions}

In this paper we analyze the impact of the three constituent elements of the new firm paradigm, i.e. intensive use of ICT, redesign of workplace organization and augmenting the input of human capital, on the provision of apprenticeship 
training. The investigation is expected to give some indication of the appropriateness of the apprenticeship system as a way of skill formation in a highly advanced knowledge-based economy where the new firm paradigm plays a significant role.

In case of training propensity, there is strong evidence for a positive impact of two out of the three constituent elements of the new firm model: a) human capital intensity: positive effect of the employment share of workers with tertiary-level qualifications and b) ICT intensity: positive overall effect reflecting the availability of ICT infrastructure, the degree of intra-firm diffusion of the intranet and the variety of Internet applications. These results may be qualified by the observation that at the very highest level of both human capital and ICT intensity the propensity of apprenticeship training is not higher than in the reference group (firms with a low intensity of use of human capital and ICT respectively). The third core element of the new firm paradigm, i.e. the redesign of workplace organization, is less important as a determinant of training propensity. We find a significantly positive effect only for one of the five organizational dimensions taken into consideration ('incidence of teamwork within the firm'), whereas the impact of a decentralization of competencies is negative. In sum, the results for training propensity suffice to conclude that apprenticeship training seems to be an appropriate way of skill formation in an advanced economy where the new firm paradigm plays a significant role. However, this may not be the case in the (technologically) most sophisticated segments of the economy.

In case of training intensity also two of the three core elements turn out to be statistically significant: a) human capital intensity: positive effect of the share of employees with tertiary education and b) workplace organization: positive effect of a reduction of the number of hierarchical levels. ICT does not directly influence the intensity of training provision, but there is evidence for a positive indirect effect of ICT reflecting the complementarity of ICT and workplace organization. Again we find some evidence (though weaker than in case of training propensity) that apprenticeship training is less widespread in technologically leading activities.

The findings with respect to ICT, workplace organization and human capital are encouraging for policy makers dealing with the Swiss apprenticeship system. They imply that the Swiss system is quite appropriate to accommodate the significant changes required for a transition to the new firm paradigm that plays an increasing role in economically advanced countries. This assessment may be qualified in one respect: the apprenticeship system without any doubt is very effective in providing skills in an advanced economy, but there is some evidence that this may not be the case in (technologically) leading-edge activities. It is up to further research to appraise this tentative conclusion. In any case, the reform 
of higher professional education in Switzerland realized in the late 1990s, particularly the establishment of universities of applied sciences (which provide sciencebased education mostly on top of apprenticeship training), is well-suited to counteract the (potential) weakness of the apprenticeship system we mentioned above. 


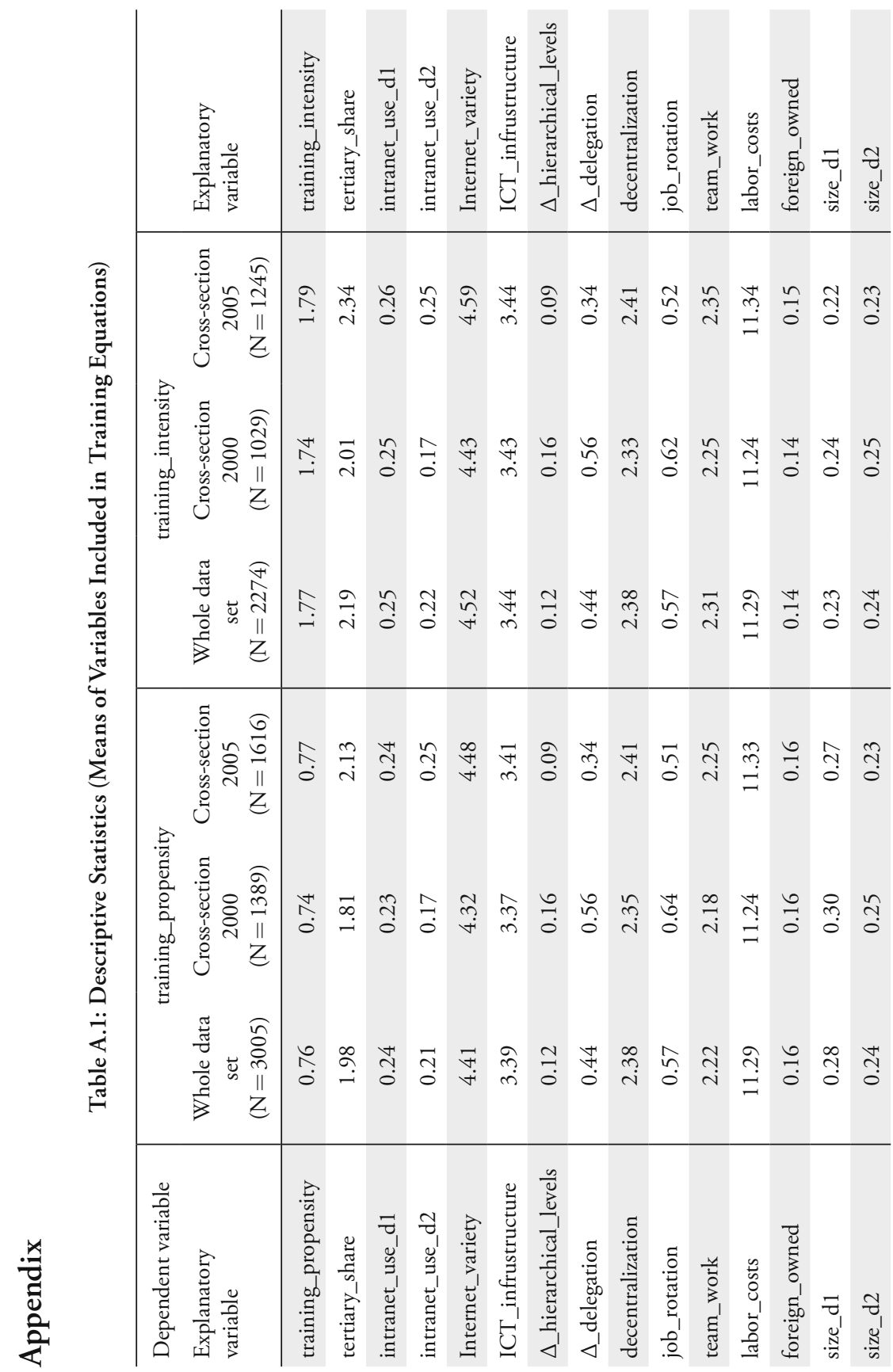




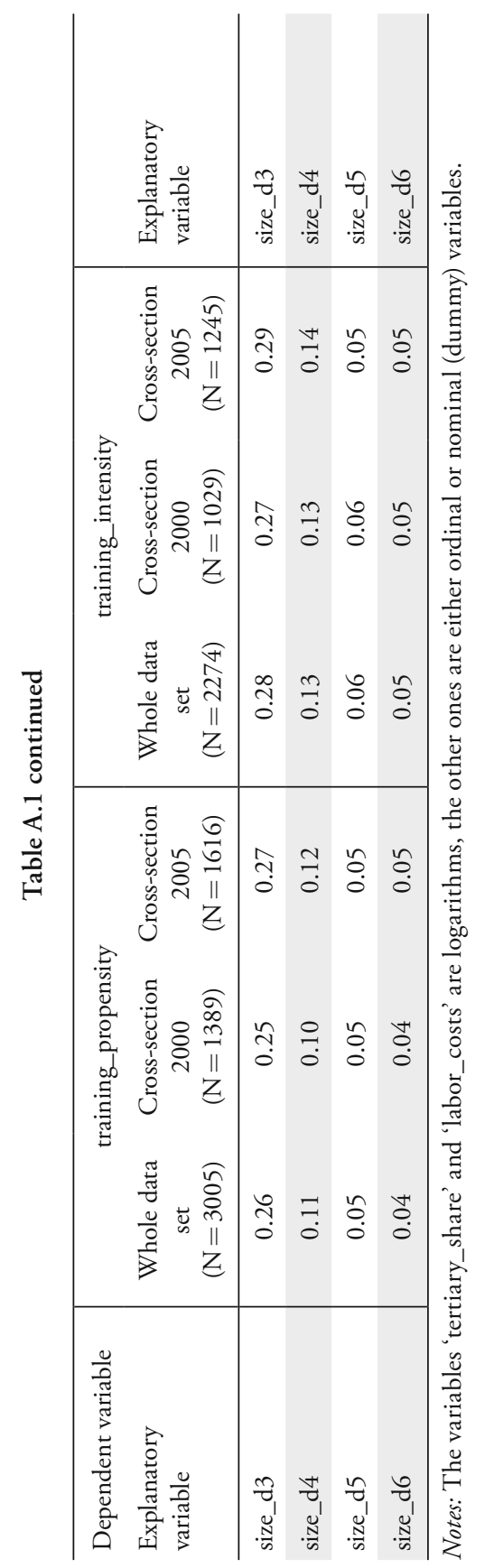




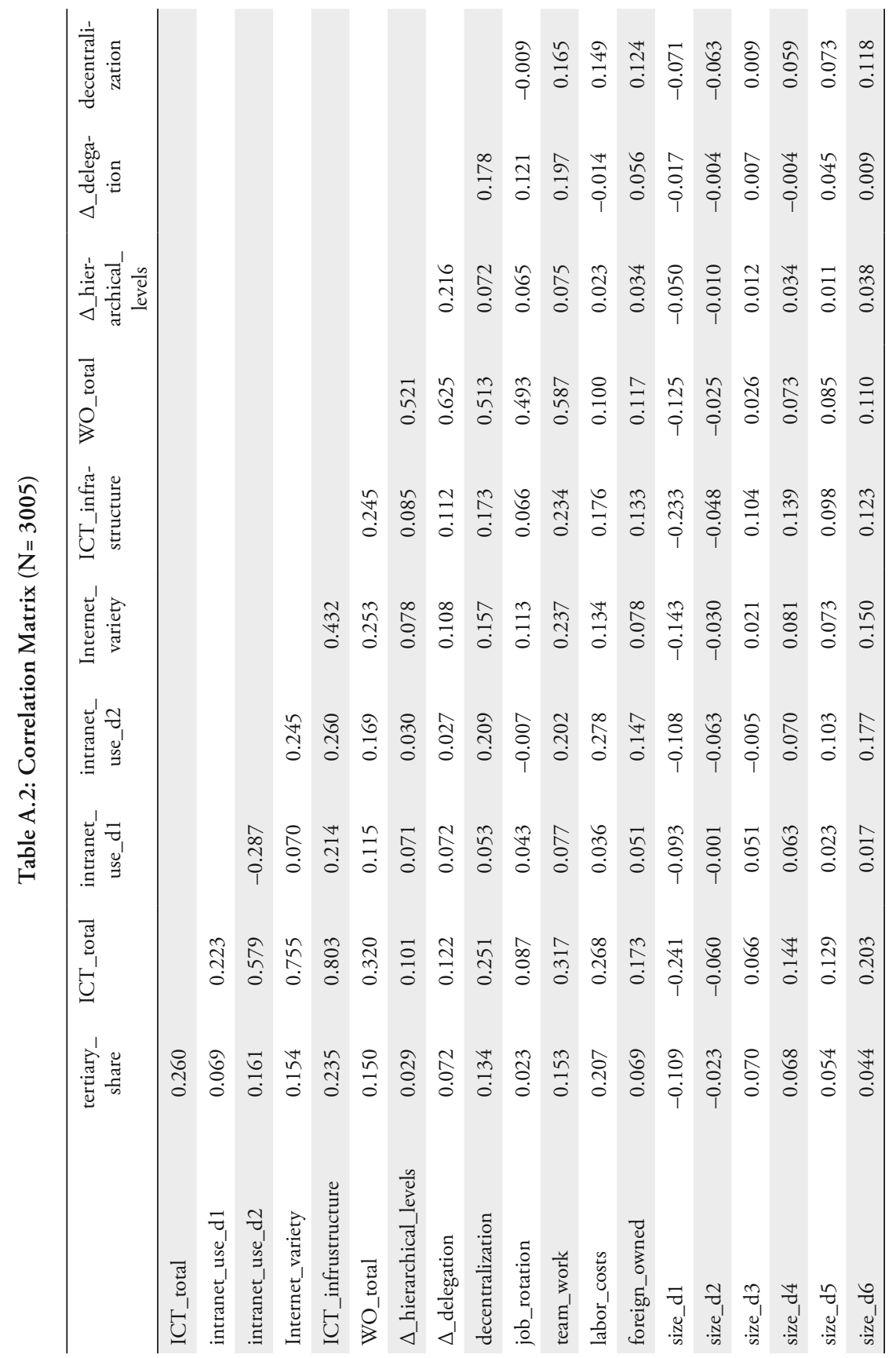




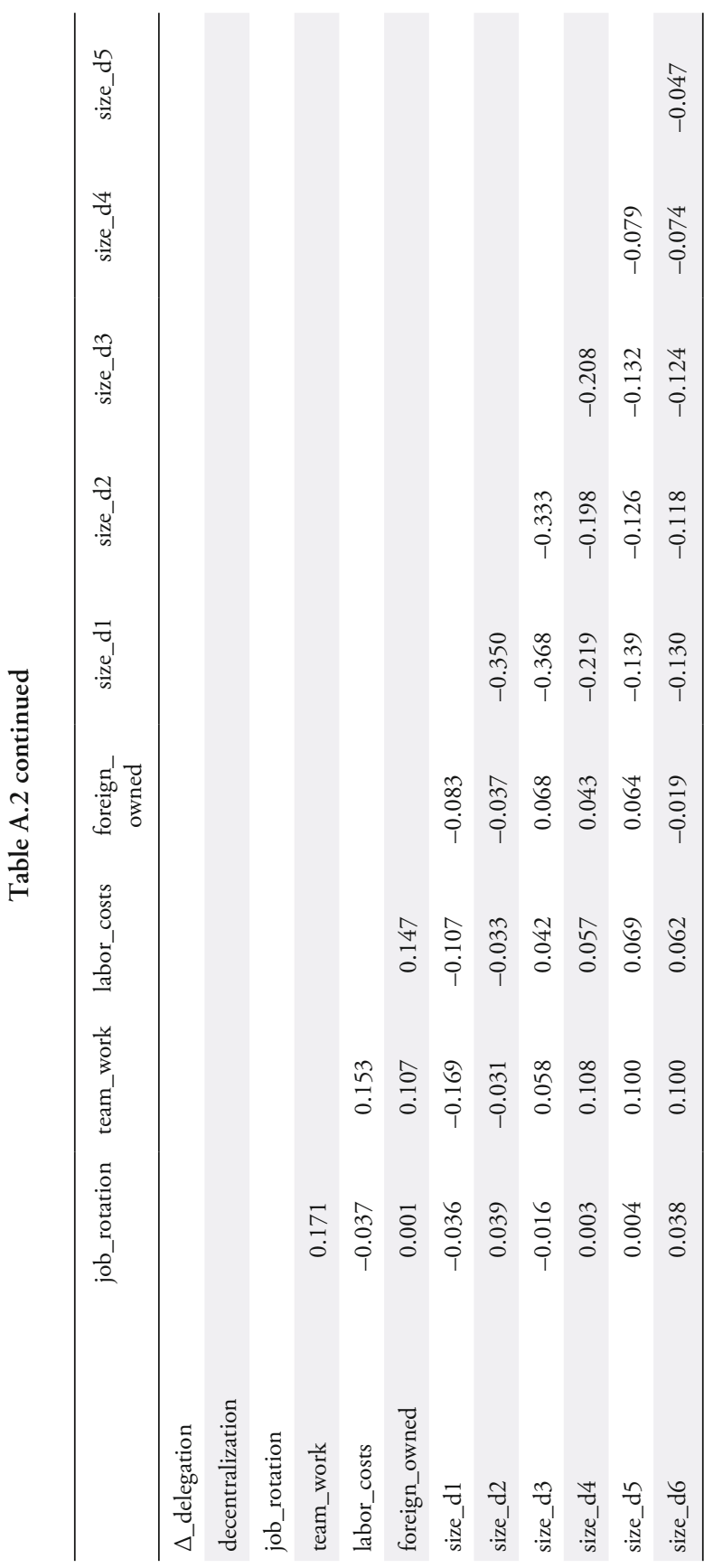


Table A.3: Testing for Sample Selection (Heckman Selection Model)

\begin{tabular}{|c|c|c|c|}
\hline \multirow[b]{2}{*}{ Dependent variable } & \multirow{2}{*}{$\begin{array}{c}\text { OLS } \\
\text { Training } \\
\text { intensity }\end{array}$} & \multicolumn{2}{|c|}{ Heckman } \\
\hline & & $\begin{array}{l}\text { Training } \\
\text { intensity }\end{array}$ & $\begin{array}{l}\text { Training } \\
\text { propensity }\end{array}$ \\
\hline tertiary_share & $\begin{array}{c}0.016^{* *} \\
(0.008)\end{array}$ & $\begin{array}{c}0.016^{*} \\
(0.009)\end{array}$ & $\begin{array}{c}0.034^{* * *} \\
(0.009)\end{array}$ \\
\hline ICT_total & $\begin{array}{c}0.015 \\
(0.010)\end{array}$ & $\begin{array}{c}0.015 \\
(0.011)\end{array}$ & $\begin{array}{l}0.051^{* * *} \\
(0.014)\end{array}$ \\
\hline WO_total & $\begin{array}{c}0.011 \\
(0.007)\end{array}$ & $\begin{array}{c}0.011 \\
(0.007)\end{array}$ & $\begin{array}{c}-0.011 \\
(0.011)\end{array}$ \\
\hline labor_costs & $\begin{array}{c}-0.294^{* * *} \\
(0.066)\end{array}$ & $\begin{array}{c}-0.294^{* * *} \\
(0.067)\end{array}$ & $\begin{array}{c}-0.168^{*} \\
(0.092)\end{array}$ \\
\hline foreign_owned & $\begin{array}{c}-0.062 \\
(0.051)\end{array}$ & $\begin{array}{c}-0.061 \\
(0.069)\end{array}$ & $\begin{array}{c}-0.400^{* * *} \\
(0.075)\end{array}$ \\
\hline size_d1 & $\begin{array}{l}0.377^{* *} \\
(0.149)\end{array}$ & $\begin{array}{l}0.377^{* *} \\
(0.151)\end{array}$ & $\begin{array}{c}0.189 \\
(0.168)\end{array}$ \\
\hline size_d2 & $\begin{array}{l}0.733^{* * *} \\
(0.150)\end{array}$ & $\begin{array}{l}0.732^{* * *} \\
(0.170)\end{array}$ & $\begin{array}{l}0.585^{* * *} \\
(0.171)\end{array}$ \\
\hline size_d3 & $\begin{array}{l}1.345^{* * *} \\
(0.151)\end{array}$ & $\begin{array}{l}1.344^{* * *} \\
(0.190)\end{array}$ & $\begin{array}{l}0.907^{* * *} \\
(0.172)\end{array}$ \\
\hline size_d4 & $\begin{array}{l}2.049^{* * *} \\
(0.154)\end{array}$ & $\begin{array}{l}2.048^{* * *} \\
(0.219)\end{array}$ & $\begin{array}{l}1.348^{* * *} \\
(0.195)\end{array}$ \\
\hline size_d5 & $\begin{array}{l}2.773^{* * *} \\
(0.164)\end{array}$ & $\begin{array}{l}2.772^{* * *} \\
(0.218)\end{array}$ & $\begin{array}{l}1.174^{* * *} \\
(0.217)\end{array}$ \\
\hline size_d6 & $\begin{array}{l}4.070^{* * *} \\
(0.182)\end{array}$ & $\begin{array}{l}4.069^{* * *} \\
(0.244)\end{array}$ & $\begin{array}{l}1.620^{* * *} \\
(0.251)\end{array}$ \\
\hline year_2005 & $\begin{array}{c}0.040 \\
(0.036) \\
\end{array}$ & $\begin{array}{c}0.040 \\
(0.037) \\
\end{array}$ & $\begin{array}{c}0.092^{*} \\
(0.055) \\
\end{array}$ \\
\hline industry_wage_individual_performance & $\begin{array}{c}0.014 \\
(0.143) \\
\end{array}$ & & $\begin{array}{l}0.532^{* * *} \\
(0.198)\end{array}$ \\
\hline constant & $\begin{array}{l}2.548^{* * *} \\
(0.933)\end{array}$ & $\begin{array}{l}2.600^{* * *} \\
(0.774)\end{array}$ & $\begin{array}{c}-0.899 \\
(1.295)\end{array}$ \\
\hline Region dummies & yes & yes & yes \\
\hline Industry dummies & yes & yes & yes \\
\hline $\mathrm{N}$ & 2270 & \multicolumn{2}{|c|}{2270} \\
\hline $\mathrm{F}$ & $60.93^{* * *}$ & & \\
\hline $\mathrm{R}^{2}$ & 0.587 & & \\
\hline Wald chi ${ }^{2}$ & & \multicolumn{2}{|c|}{$1761.38^{* * *}$} \\
\hline rho & & \multicolumn{2}{|c|}{-0.00134} \\
\hline LR test of rho $=0:$ Prob $>\mathrm{chi}^{2}$ & & \multicolumn{2}{|c|}{0.997} \\
\hline
\end{tabular}

Notes: See Table 1 for the variable definitions; standard errors are in brackets under the coefficients; ***, ${ }^{* *},{ }^{*}$ denotes statistical significance at the $1 \%, 5 \%$ and $10 \%$ test level, respectively. 


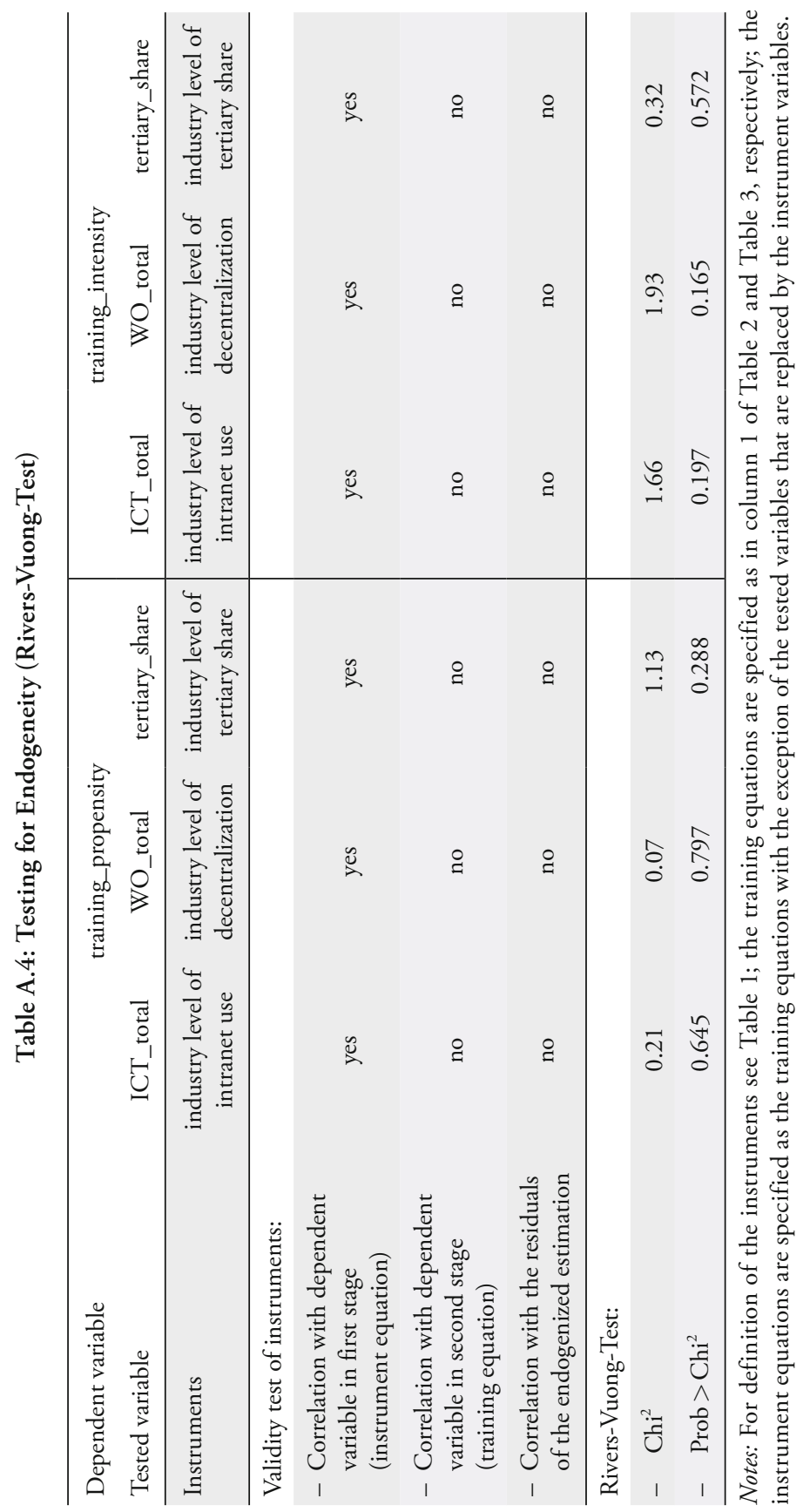




\section{References}

Acemoglu, D., and J.-S. Pischke (1998), "Why Do Firms Train? Theory and Evidence", Quarterly Journal of Economics, 113, pp.79-119.

Acemoglu, D., and J.-S. Pischke (1999), "Beyond Becker: Training in Imperfect Labour Markets”, Economic Journal, 109, pp. 112-142.

Arvanitis, S. (2005), "Information Technology, Workplace Organization and the Demand for Labour of Different Skills: Firm-Level Evidence for the Swiss Economy", in H. Kriesi, P. Farago, M. Kohli and M. Zarin-Nejadan (Eds.), Contemporary Switzerland: Revisiting the Special Case, pp. 135-162, Palgrave Macmillan, New York and Houndmills.

Arvanitis, S. (2010), "Are Firm Innovativeness and Firm Age Relevant for the Supply of Vocational Training? A Study Based on Swiss Micro Data", Open Economics Journal, 3, pp. 43-57.

Arvanitis, S., and E. N. Loukis (2009), "Employee Education, Information and Communication Technology, Workplace Organization and Trade: A Comparative Analysis of Greek and Swiss Enterprises", KOF Working Papers No.34, ETH Zurich.

Arvanitis, S., and T. Stucki (2011), "Training Propensity of Start-ups in Switzerland - A Study Based on Data for the Start-up Cohort 1996/97”, The IUP Journal of Entrepreneurship Development, 7(4), pp. 6-40.

Autor, D. H., F. Levy, and R. Murnane (2003), "The Skill Content of Recent Technological Change: An Empirical Exploration”, Quarterly Journal of Economics, 113, pp. 1169-1213.

Becker, G. S. (1964), Human Capital, The University of Chicago Press, Chicago.

Beckmann, M. (2002), „Lohnstrukturverzerrung und betriebliche Ausbildung. Empirische Analyse des Acemoglu-Pischke-Modells mit Daten des IABBetriebspanels", Mitteilungen aus der Arbeitsmarkt- und Berufsforschung, 35, pp. 189-204.

Beckmann, M. (2008), "Wage Compression and Firm-sponsored Training in Germany: Empirical Evidence for the Acemoglu-Pischke Model from a Zeroinflated Count Data Model", Applied Economics Quarterly (Konjunkturpolitik), 48, pp. 368-389.

Beicht, U., G. Walden, and H. Herget (2004), Kosten und Nutzen der betrieblichen Berufsbildung in Deutschland, Bertelsmann, Bielefeld.

Bertschek, I., and U. Kaiser (2004), "Productivity Effects of Organizational Change: Microeconometric Evidence", Management Science, 50(3), pp. 394-404. 
Bocquet, R., and O. Brossard (2007), "The Variety of ICT Adopters in the Intra-firm Diffusion Process: Theoretical Arguments and Empirical Evidence", Structural Change and Economic Dynamics, 18, pp.409-437.

Bresnahan, T. F. (1999), "Computerisation and Wage Dispersion: An Analytical Reinterpretation”, Economic Journal, 109, pp.390-415.

Bresnahan, T. F., E. Brynjolfsson, and L. M. Hitt (2002), "Information Technology, Workplace Organisation, and the Demand for Skilled Labour: Firm-Level Evidence", Quarterly Journal of Economics, 112, pp. 339-376.

Burns, T., and G. Stalker (1994), The Management of Innovation, $3^{\text {rd }}$ Edition, (first published in 1961), Oxford University Press: Oxford.

Caroli, E. (2001), "New Technologies, Organizational Change and the Skill Bias: What Do we Know?", in P. Petit and L. Soete (Eds.), Technology and the Future of European Employment, pp. 259-292, Elgar, Cheltenham.

Cassiman, B., and R. Veugelers (2002), "R\&D Cooperation and Spillovers: Some Empirical Evidence from Belgium”, American Economic Review, 92(4), pp. 1169-1184.

Dustmann, C., and U. Schönberg (2009), "Training and Union Wages", Review of Economics and Statistics, 91, pp. 363-376.

Elbaum, B., and N. Singh (1995), "The Economic Rationale of Apprenticeship Training: Some Lessons from British and U.S. Experience", Industrial Relations, 34, pp. 593-622.

European Commission (2007b), The European E-business Report, 2006/07, DG Enterprise and Industry, Luxembourg, available at: www.ebusiness-watch.org/ about/methodology.htm (accessed 16 September 2009).

Finegold, D., and K. Wagner (2002), "Are Apprenticeships Still Relevant in $21^{\text {st }}$ Century? A Case Study of Changing Youth Training Arrangements in German Banks", Industrial and Labour Relations Review, 55, pp. 667-685.

Franz, W., and D. Soskice (1995), "The German Apprenticeship System”, in F. Buttler, W. Franz, R. Schettkat and D. Soskice (Eds), Institutional Frameworks and Labor Market Performance, pp. 208-234, Routledge, London.

Franz, W., V. Steiner, and V. Zimmermann (2000), „Die betriebliche Ausbildungsbereitschaft im technologischen und demographischen Wandel“, $Z E W$ Wirtschaftsanalysen, 46, Nomos, Baden-Baden.

Gersbach, H., and A. Schmutzler (2012), "A Product-Market Theory of Industry-Specific Training”, RAND Journal of Economics, forthcoming. Harhoff, D., and T. J. Kane (1997), "Is the German Apprenticeship System a Panacea for the U.S. Labor Market?", Journal of Population Economics, 2, pp. 171-196. 
Heckman, J. J. (1979), "Sample Selection Bias as a Specification Error", Econometrica, 47, pp. 153-161.

Hollenstein, H., N. Sydow, and M. WÖRTer (2003), Einsatz von Informationsund Kommunikationstechnologien in den Schweizer Unternehmen, KOF/ETHPanelumfrage 2002 mit internationalen Vergleichen, edited by the Bundesamt für Statistik (BFS), Neuchâtel.

Kessler, A. S., and C. Lülfesmann (2006), "The Theory of Human Capital Revisited: On the Interaction of General and Specific Investments", Economic Journal, 116, pp. 903-923.

Lindbeck, A., and D. Snower (2000), "Multitask Learning and the Reorganization of Work: From Tayloristic to Holistic Organization", Journal of Labor Economics, 18, pp.353-376.

Milgrom, P., and J. Roberts (1990), "The Economics of Modern Manufacturing: Technology, Strategy, and Organization”, American Economic Review, 80 , pp. 511-528.

Muehlemann, S., H. Pfeifer, G. Walden, F. Wenzelmann, and S. C. Wolter (2010), "The Financing of Apprenticeship Training in the Light of Labour Market Regulations”, Labour Economics, 17, pp. 799-809.

Niederalt, M. (2004), Zur ökonomischen Analyse betrieblicher Lehrstellenangebote in der Bundesrepublik Deutschland, Peter Lang, Frankfurt am Main.

Piva, M., E. Santarelli, and M. Vivarelli (2005), "The Skill Bias Effect of Technological and Organisational Change: Evidence and Policy Implications", Research Policy, 34, pp. 141-157.

Ryan, P. (2001), "The School-to-Work Transition: A Cross-National Perspective", Journal of Economic Literature, 39, pp. 34-92.

Ryan, P., and S. C. Wolter (2011), "Apprenticeship", in: E. A. Hanushek, S. Machin, L. Wössmann (eds.), Handbook of Economics of Education, Volume 3, pp. 521-576, Amsterdam: Elsevier North-Holland.

Schweri, J., S. Mühlemann, Y. Pescio, B. Walther, S. C. Wolter, and L. ZürCher (2003), Kosten und Nutzen der Lehrlingsausbildung aus der Sicht Schweizer Betriebe. Rüegger, Chur-Zürich.

Steedman, H. (2001) "Benchmarking Apprenticeship: UK and Continental Europe Compared”, London School of Economics, Centre for Economic Performance (CEP), Discussion Paper No. 0513, London.

Steedman, H. (2005), "Apprenticeship in Europe: Fading or Flourishing?", London School of Economics, Centre for Economic Performance (CEP), Discussion Paper No. 0710, London. 
Wolter, S.C., and J. Schweri (2002), "The Cost and Benefit of Apprenticeship Training: The Swiss Case", Applied Economics Quarterly (Konjunkturpolitik), 48, pp. 347-367.

Wooldridge, J.M. (2002a), Econometric Analysis of Cross Section and Panel Data, The MIT Press, Cambridge, Massachusetts, London, England.

Wooldridge, J.M. (2002b), Introductory Econometrics. A Modern Approach, South-Western College Publishing, Thomson Learning, Mason, USA.

\section{SUMMARY}

The paper analyzes the relevance of the three constituent elements of the 'new firm paradigm', i.e. ICT, workplace organization and human capital, as determinants of a firm's provision of training. We concentrate on apprenticeship training, which in German-speaking countries is a widespread practice of skill formation. Econometric studies dealing with a firm's provision of apprenticeships so far did not pay much attention to the influence of a shift towards the new paradigm. We find that apprenticeship training is an appropriate way of skill formation in advanced economies, but this may not be the case in leading-edge segments of the economy. 